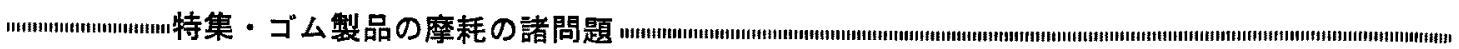

\title{
自動車用タイヤの摩 耗
}

ゴム工業技術員会 第13分科会（自動車タイヤ）

副主查 山 本 博 美

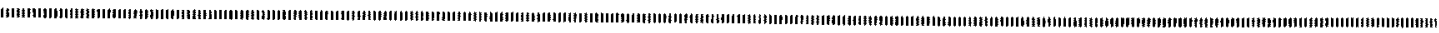

\section{1. まえがき}

日本ゴム協会の第 6 回ゴム技術シンポジウム「ゴム製 品の摩耗」に関する共同研究のために, ゴム工業技術員 会第 3 特別研究委員会が設けられ，「自動車用タイヤの 摩耗」についてゴム工業技術員会第13分科会（自動車夕 イヤ）が担当し，日本自動車タイヤ協会最高技術会議を 通じ，故松平信孝主查を中心に材料委員会扰よび試験委 員会がそれぞれ実験室試験および実車走行試験を実施し た. 試験目的として, 実験室摩耗試験機による摩耗と実 車走行試験による摩耗との関連を研究調查するため, ト ラック用タイヤ抗よび乗用車用タイヤについて，それぞ れ 2 種類のトレッド配合 (A-T 配合，B-T 配合および A-P 配合，B-P 配合）の各テストタイヤを供試し，実車 走行試験とともに各配合ゴムの実験空試験ならびに摩耗 面の電子顕微鏡写真の観察を検討した。

\section{2. 試験項目および試験内容}

トレッド摩耗の重要因子であるゴムおよびカーボンブ ラックについて，次のようなテストトレッド配合により 実車走行供試タイヤを作製し，同一工場の練りゴムバッ チのテスト配合ゴムについて実験窒試験を行なった.

トラック用タイヤトレッド配合
A-T: $80 \mathrm{NR} / 20 \mathrm{BR}-50$ ISAF
B-T: $80 \mathrm{NR} / 27.5$ SBR 1712-50HAF

乗用車用タイヤトレッド配合

A-P: 70 SBR1712/30BR-85.IISAF

B-P: 80 SBR1712/20BR-85HAF

\section{1 実験空試験}

(1) 摩耗試験
a.ピコ摩耗試験嘰
b.アロンク摩耗䟼験機

*住友ゴム工業株式会社

（画 651 神户市㯰合区筒井町 1-20) c。ウイリアムス摩耗試験機

d. 改良ランボーン摩耗試験機

e.ランポーン摩耗試験機

各試験は末老化試料扰よび熱老化試料 $\left(100^{\circ} \mathrm{C} \times 48 \mathrm{~h}\right.$ ， 架気オーブン）について奏施した。試験条件は各試験機 の試験担当会社における標準条件とともに過酷度を，乙 れぞれ上下したものについて試験することにした。 ピコ 摩耗試験については実龭室加硫試料のほかに，実車走行 タイヤのトレッド (走行前後)より採取した試料の摩耗 試験を実施した。

(2) 物性試験

a . 引張試験（引張強さ， $300 \%$ 引張応力, 伸び， 引裂強さ，かたさ）

b . 反ぱつ彈性試験

c. カーボン分散試験

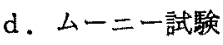

引張試験および反ぱつ弾性試験は, 未老化試料および 熱老化試料について実施した．カーボン分散試験は供験 タイヤトレッドより採取の試料について実施した.

(3) 電子顕微鏡写.真 (レプリカ法)

実験室摩耗試験の試料摩耗面杍よび実車走行試験終了 後のトレッド摩耗面について, 電子顕微鏡レプリカ写真 をとり，摩耗面の観察比較を行なった。

\section{2 実車走行試験}

\begin{tabular}{lllr} 
(1) 試騒タイヤ & \multicolumn{2}{c}{ 試験トレッド本数 } \\
トラック 10.00-20 14PR HT-Lug & A-T 配合 & 12 本 \\
& B-T"T" & 12本 \\
乗用車 5.60-13 4PR & A-P配合 & 12 本 \\
& B-P" " & 12本
\end{tabular}

(2) 試験台数扝よび試験条件（表 $\mathrm{S}$ 参照）

(3) 測定方法

深度法：タイヤトレッドのみぞ深さをデプスゲージ で測定し，摩耗量 $(\mathrm{mm})$ と走行 $\mathrm{km}$ を記 䘵した。 
重量法：タイヤ重量を装着前と走行試験終了後取り

はずして測定し，摩耗量 $(\mathrm{kg})$ を記録した。

深度法に扔いては，摩耗測定位置はトレッド配合の識 別マーク (A，B) を基準とし，円周方向 4 加所について， トラックの場合指定みぞ位笽，乗用車の場合全みぞを測 定した，深度測定は装着時，位置交換時扝よび走行試験 終了取りはずしたときに実施した。

表 S 試験台数と試験条件

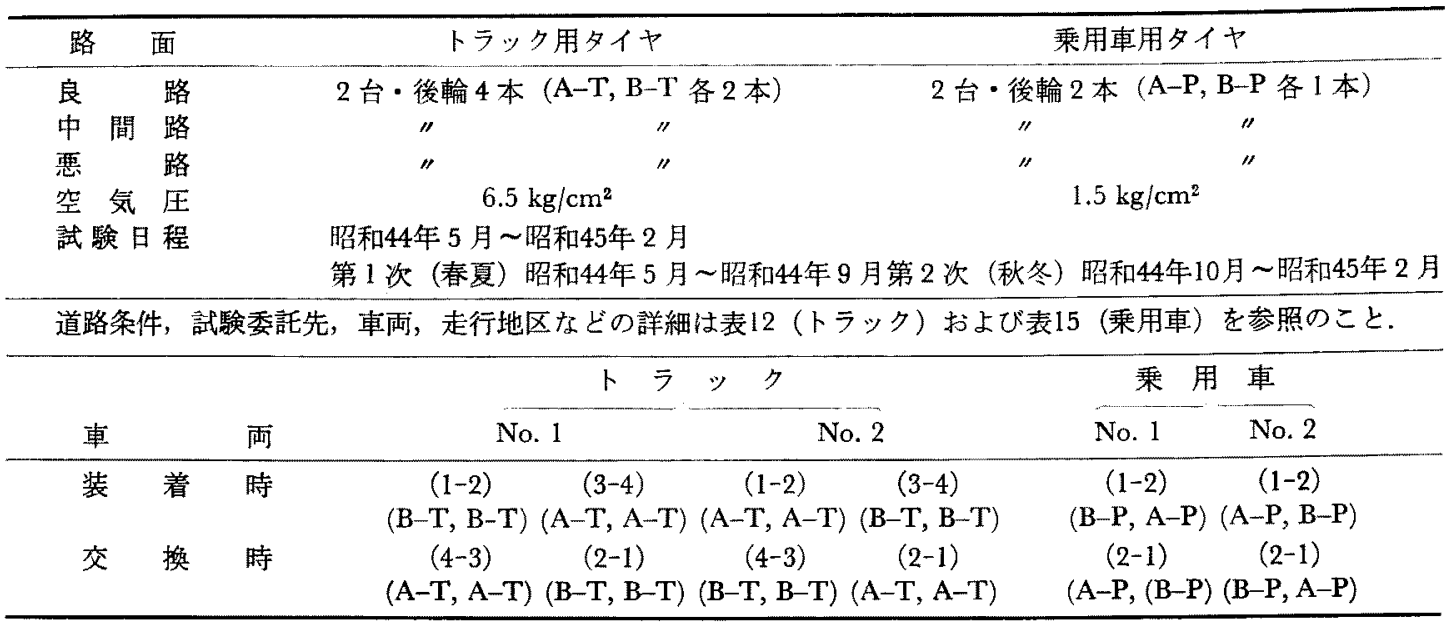

\section{3. 試 験 結 果}

\section{1 実験室試験結果}

(1) トラック用タイヤトレッド配合 ピコ摩耗試験結果（表 1，図 1) アクロン摩耗試験結果（表 2, 図 2)

ウイリアムス摩耗試験結果（表 3, 図 3） 改良ランボーン摩耗試験結果（表 4, 図 4)
タイヤの位置交换は次のと扔り実施し，みぞ深さと同 時にトレッドかたさ怙よび損賃状態なども参考に記 録 し，あわせて規定空気圧に調整を行なった，位置交換は 原則としてトラックの場合, 良路执よび中間路走行では, $10,000 \mathrm{~km}$ ごととし, 悪路走行では $5,000 \mathrm{~km}$ ごととし

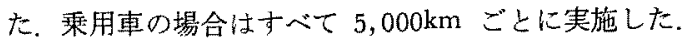




\section{2 実車走行試験結果}

(1) トラック用タイヤ 媣度法測定結果（表12，表13）

重量法測定結果（表14，図10)

（2）乗用車用タイヤ

樑度法测定結果（表15，表16）

重量法测定結果（表17）

\section{3 電子顕微鏡レブリカ写真（図12）}

表1-2 ピコ摩耗試験結果：トラックタイ ヤトレッドより試料採取 (B社)

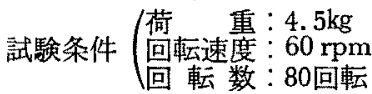

単位：cc

\begin{tabular}{|c|c|c|}
\hline 采取試料 配合 & $A-T$ & $\mathrm{~B}-\mathrm{T}$ \\
\hline 走 行 前 & $0.0102(190)$ & $0.0194(100)$ \\
\hline $\begin{array}{l}\text { 息路走行後 } \\
(100 \% \text { 舗荠) }\end{array}$ & $0.0138(117)$ & $0.0162(100)$ \\
\hline $\begin{array}{l}\text { 中間路走行後 } \\
(95 \% \text { 舗 装) }\end{array}$ & $0.0145(118)$ & $0.0171(100)$ \\
\hline $\begin{array}{l}\text { 墨 路走行 後 } \\
(50 \% \text { 舖 装) }\end{array}$ & $0.0109(126)$ & $0.0137(100)$ \\
\hline
\end{tabular}

\section{(LOSS : CC/80REV.)}

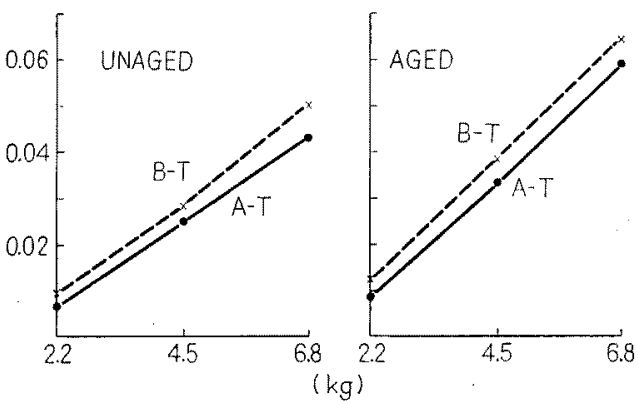

図1-(1) ピコ摩耗試験結果：トラック用タイヤ トレッド配合（A社試験）

(LOSS : CC/ 80 REV.)

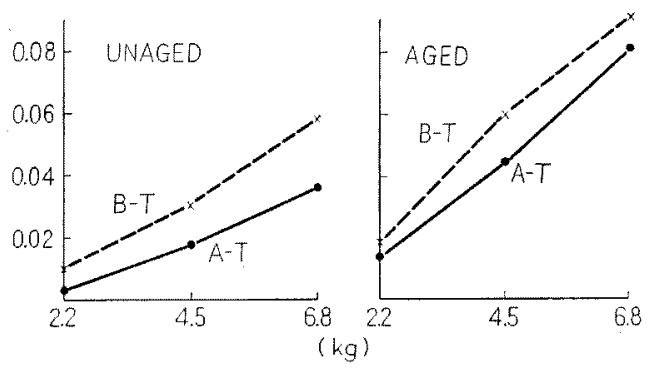

図1-(2) ピコ摩耗試験結果 : トラック用タイヤ トレッド配合（B 社試験）
(LOSS : CC/ 1000REV.)

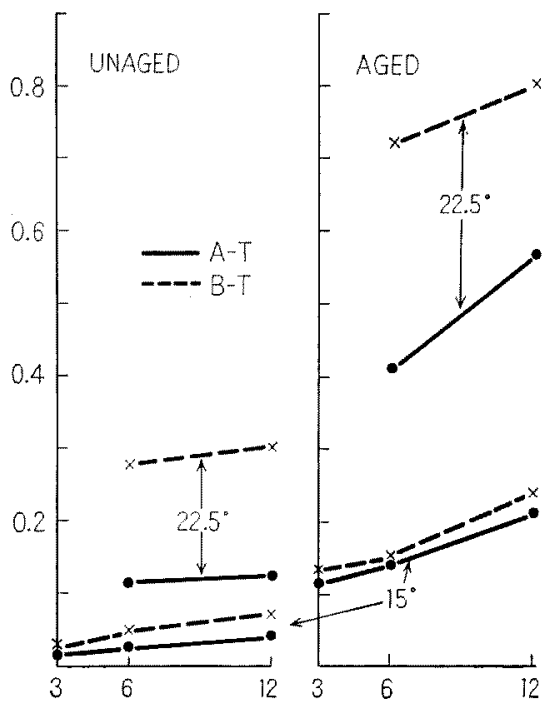

(lb)

図 2 アクロン摩耗試験結果：トラック用 タイヤトレッド配合（G社試験）

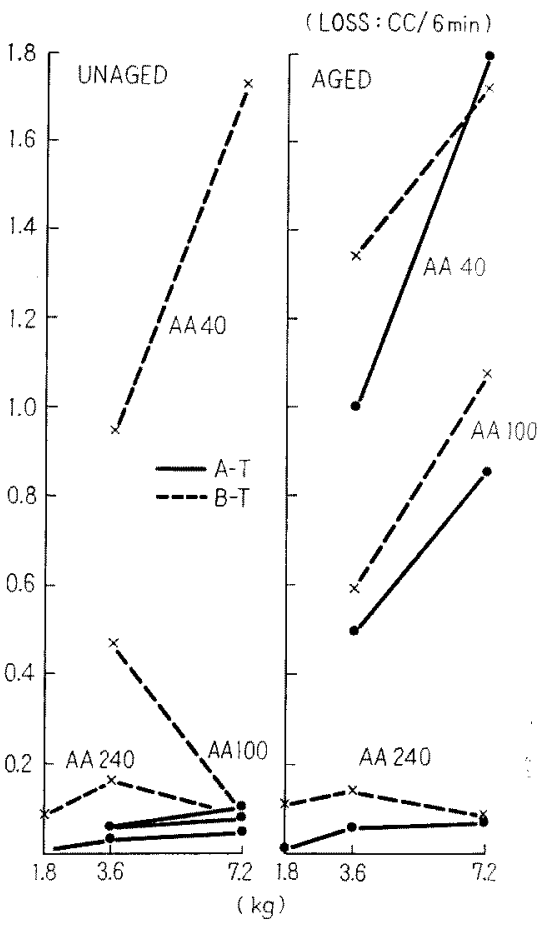

図 3 ウィリアムス摩耗試験結果 : トラック用 タイヤトレッド配合（G社試験） 
表2 アクロン摩耗試験結果：トラック用タイヤトレッド配合（G社）

試験条件 $\left(\begin{array}{l}\text { 荷 重: } 3 \mathrm{lb}, 6 \mathrm{lb}, 12 \mathrm{lb} \\ \text { 第鉣数: }: 100 \mathrm{rpm}\end{array}\right.$

単位: $\mathrm{cc} / 1000$ 回 (試験数 $\mathrm{n}=3$ )

(1) 老 化 前

\begin{tabular}{|c|c|c|c|c|c|c|}
\hline \multirow[b]{3}{*}{ 荷重 } & \multicolumn{3}{|c|}{$A-T$} & \multicolumn{3}{|c|}{$B-T$} \\
\hline & \multicolumn{3}{|c|}{$\left(140^{\circ} \mathrm{C} \times 40\right.$ 分 $)$} & \multicolumn{3}{|c|}{$\left(140^{\circ} \mathrm{C} \times 40\right.$ 分 $)$} \\
\hline & $7.5^{\circ}$ & $15^{\circ}$ & $22.5^{\circ}$ & $7.5^{\circ}$ & $15^{\circ}$ & $22.5^{\circ}$ \\
\hline $31 \mathrm{~b}$ & 0.004 & 0.015 & - & 0.004 & 0.023 & - \\
\hline $61 \mathrm{~b}$ & 0.008 & 0.023 & 0.110 & 0.007 & 0.046 & 0.275 \\
\hline \multirow[t]{2}{*}{$121 \mathrm{~b}$} & - & 0.042 & 0.123 & - & 0.069 & 0.298 \\
\hline & \multicolumn{3}{|c|}{$\left(140^{\circ} \mathrm{C} \times 60\right.$ 分 $)$} & \multicolumn{3}{|c|}{$\left(140^{\circ} \mathrm{C} \times 60\right.$ 分 $)$} \\
\hline $3 \mathrm{lb}$ & 0.003 & 0.013 & 一 & 0.003 & 0.027 & 一 \\
\hline $6 \mathrm{lb}$ & 0.005 & 0.025 & 0.098 & 0.009 & 0.039 & 0.268 \\
\hline $12 \mathrm{lb}$ & 一 & 0.036 & 0.104 & - & 0.052 & 0.299 \\
\hline
\end{tabular}

(2) 熱老化後 $\left(100^{\circ} \mathrm{C} \times 48 \mathrm{~h}\right.$ オープン)

\begin{tabular}{|c|c|c|c|c|c|c|c|}
\hline & & \multicolumn{3}{|c|}{$\left(140^{\circ} \mathrm{C} \times 60\right.$ 分 $)$} & \multicolumn{3}{|c|}{ (140 $\mathrm{C} \times 60$ 分) } \\
\hline & 1 千回 & 0.0004 & 0.089 & - & 0.0003 & 0.112 & - \\
\hline \multirow[t]{3}{*}{$3 \mathrm{lb}$} & 2 干回 & 0.005 & 0.113 & - & 0.008 & 0.132 & - \\
\hline & 3 千回 & 0.003 & $0.13 \mathrm{I}$ & - & 0.003 & 0.163 & - \\
\hline & 1 千回 & 0.005 & 0.123 & 0.436 & 0.001 & 0.124 & 0.710 \\
\hline \multirow[t]{3}{*}{$6 \mathrm{lb}$} & 2 千回 & 0.010 & 0.135 & 0.405 & 0.0009 & 0.150 & 0.745 \\
\hline & 3 千 回 & 0.013 & 0.159 & 0.392 & 0.009 & 0.173 & 0.711 \\
\hline & 1 千回 & - & 0.209 & 0.652 & - & 0.235 & 0.951 \\
\hline \multirow[t]{4}{*}{$121 \mathrm{~b}$} & 2 千回 & - & 0.221 & 0.547 & - & 0.248 & 0.776 \\
\hline & 3 干回 & 一 & 0.213 & 0.512 & - & 0.236 & 0.690 \\
\hline & & & $0^{\circ} \mathrm{C} \times 6$ & & & $0^{\circ} \mathrm{C} \times 6$ & \\
\hline & 1 千回 & 0.0004 & 0.082 & - & 0.0013 & 0.096 & - \\
\hline \multirow[t]{3}{*}{$3 \mathrm{lb}$} & $\{2$ 千回 & 0.006 & 0.105 & - & 0.008 & 0.134 & - \\
\hline & 3 千回 & 0.002 & 0.120 & - & 0.004 & 0.153 & 一 \\
\hline & 1 千回 & 0.005 & 0.101 & 0.349 & 0.0004 & 0.125 & 0.684 \\
\hline \multirow[t]{3}{*}{$6 \mathrm{lb}$} & 2 千回 & 0.009 & 0.107 & 0.343 & 0.005 & 0.180 & 0.715 \\
\hline & 3 千回 & 0.009 & 0.129 & 0.337 & 0.007 & 0.201 & 0.694 \\
\hline & 1 千回 & - & 0.181 & 0.469 & - & 0.179 & 0.819 \\
\hline \multirow[t]{2}{*}{$12 \mathrm{lb}$} & 2 千回 & - & 0.186 & 0.419 & - & 0.240 & 0.743 \\
\hline & 3 千回 & - & 0.187 & 0.403 & - & 0.231 & 0.707 \\
\hline
\end{tabular}

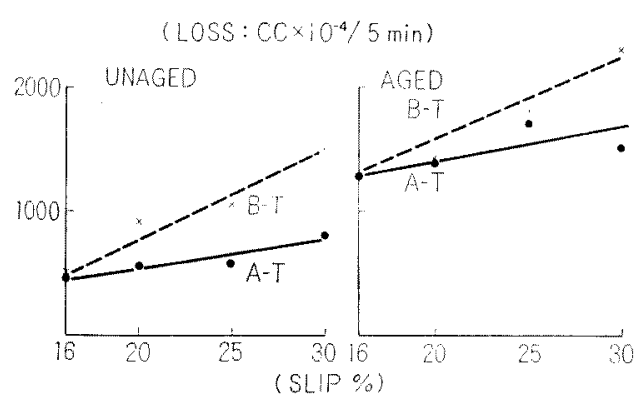

図 4 改良ランボーン摩耗試験結果 : トラック 用タイヤレッド配合（H社陚験）

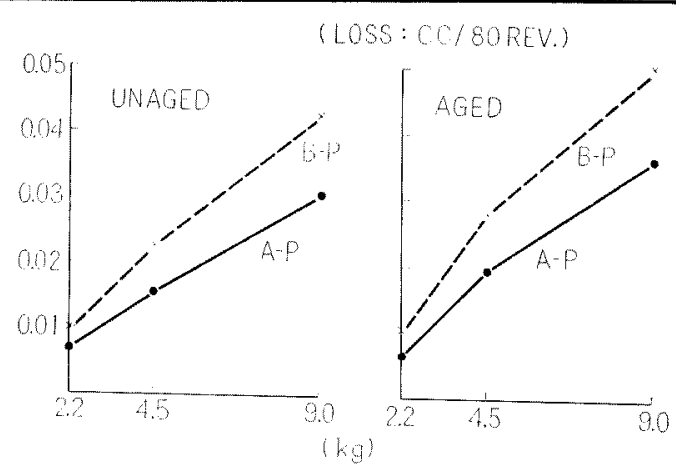

図5-(1) ピコ摩耗試験結果：乗用車用タイヤト レッド配合（B 社試験） 
表 3 ウイリアムス摩耗試駼結果：トラック用タイヤトレッド配合（G社）

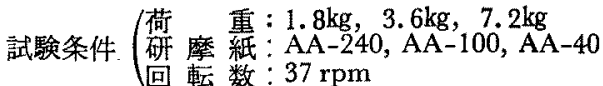

单位： $c c / 6$ 分間(試験数 $\mathrm{n}=3$ )

(1) 老 化 前

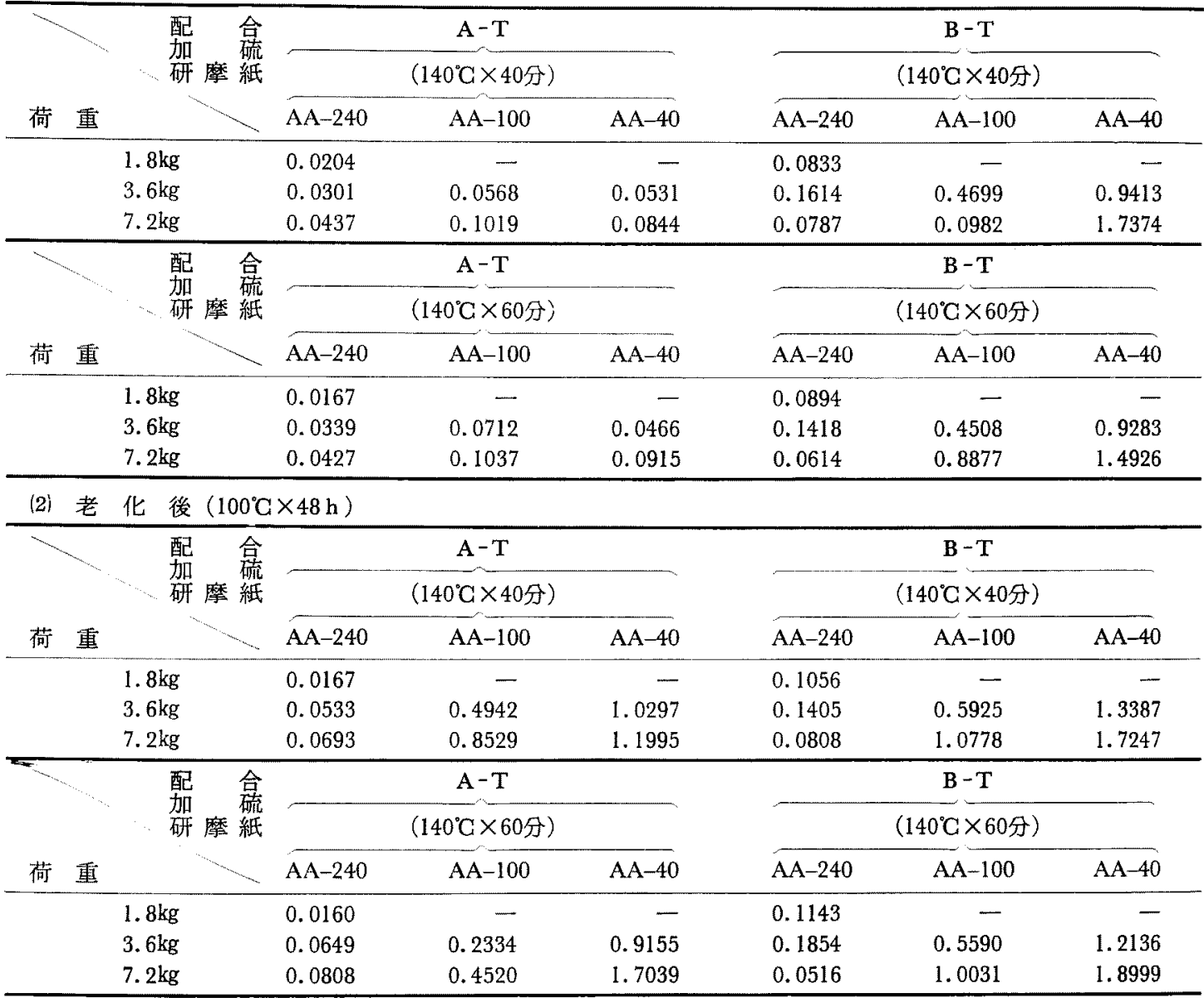

表 4 改良ランボーン摩耗試験結果：トラック用タイヤトレッド配合（H社）

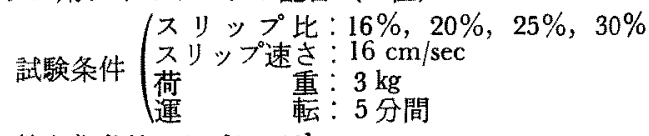

熱老化条件： $100^{\circ} \mathrm{C} \times 48 \mathrm{~h}$

単位: $\operatorname{cc} \times 10^{-4}($ 試験数 $\mathrm{n}=3$ )

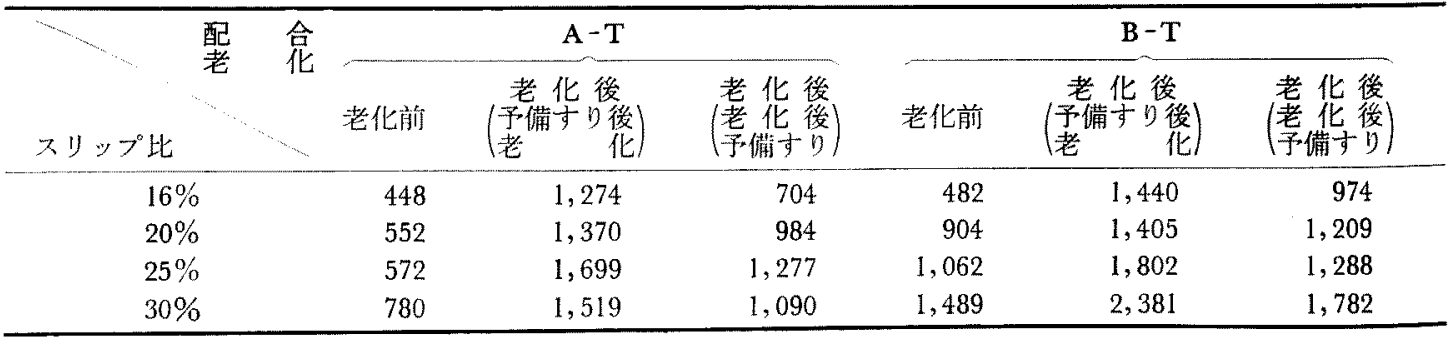


熱老化条件：100总 $\times 48 \mathrm{~h}$

\begin{tabular}{|c|c|c|c|c|c|}
\hline \multirow{2}{*}{ 物性 - 加硫 } & \multirow{2}{*}{ 配合・老化 } & \multicolumn{2}{|c|}{$A-T$} & \multicolumn{2}{|c|}{$B-T$} \\
\hline & & 老 化 前 & 老化 後 & 老 化前 & 老化後 \\
\hline \multicolumn{2}{|c|}{ ムー 一一粘度 $\mathrm{ML}_{1+4}\left(130^{\circ} \mathrm{C}\right)$} & 56 & - & 41 & - \\
\hline \multicolumn{2}{|c|}{ スコーチタイム（t 5) $130^{\circ} \mathrm{C}$ (分) } & 17 & - & 17 & - \\
\hline \multicolumn{2}{|c|}{ カーボンブラック分散度 (\%) } & 97.4 & - & 98.4 & - \\
\hline \multirow{3}{*}{$\begin{array}{c}\text { 引 張 強 さ } \\
\left(\mathrm{kg} / \mathrm{cm}^{2}\right)\end{array}$} & $141^{\circ} \mathrm{C} \times 20$ 分 & 234 & 200 & 235 & 196 \\
\hline & $141^{\circ} \mathrm{C} \times 40$ 分 & 243 & 192 & 237 & 194 \\
\hline & $141^{\circ} \mathrm{C} \times 60$ 分 & 240 & 180 & 237 & 188 \\
\hline \multirow{3}{*}{$\begin{array}{c}300 \% \text { 引張応力 } \\
\left(\mathrm{kg} / \mathrm{cm}^{2}\right)\end{array}$} & $141^{\circ} \mathrm{C} \times 20$ 分 & 83 & 132 & 82 & 121 \\
\hline & $141^{\circ} \mathrm{C} \times 40$ 分 & 97 & 126 & 93 & 116 \\
\hline & $141^{\circ} \mathrm{C} \times 60$ 分 & 96 & 121 & 94 & 113 \\
\hline \multirow{3}{*}{$(\%)$} & $141^{\circ} \mathrm{C} \times 20$ 分 & 630 & 445 & 650 & 470 \\
\hline & $141^{\circ} \mathrm{C} \times 40$ 分 & 585 & 420 & 575 & 455 \\
\hline & $141^{\circ} \mathrm{C} \times 60$ 分 & 580 & 400 & 570 & 440 \\
\hline \multirow[b]{3}{*}{$(\mathrm{JIS})$} & $141^{\circ} \mathrm{C} \times 20$ 分 & 60 & 66 & 59 & 62 \\
\hline & $141^{\circ} \mathrm{C} \times 40$ 分 & 61 & 66 & 59 & 62 \\
\hline & $141^{\circ} \mathrm{C} \times 60$ 分 & 61 & 65 & 59 & 62 \\
\hline \multirow{2}{*}{$\begin{array}{c}\text { 引裂強さ @100 } \\
(\mathrm{kg} / \mathrm{cm})\end{array}$} & $141^{\circ} \mathrm{C} \times 40$ 分 & 72 & - & 64 & - \\
\hline & $141^{\circ} \mathrm{G} \times 60$ 分 & 78 & - & 60 & - \\
\hline \multirow{2}{*}{$\begin{array}{c}\text { 反ぱつ弾性@50 } \\
(\%)\end{array}$} & $141^{\circ} \mathrm{C} \times 40$ 分 & 56.5 & 55.8 & 61.0 & 60.2 \\
\hline & $141^{\circ} \mathrm{C} \times 60$ 分 & 55.4 & 55.0 & 59.9 & 59.5 \\
\hline 比 & & 1.130 & - & 1.125 & - \\
\hline
\end{tabular}

表6-1 ピコ摩耗試験結果：乘用車用トレッド配合

試験条件(回転速度：60 rpm

熱老化条件：100 ${ }^{\circ} \mathrm{C} \times 48 \mathrm{~h}$ 単位: $\operatorname{cc}($ 試験数 $\mathrm{n}=3$ )

\begin{tabular}{|c|c|c|c|c|c|c|c|}
\hline & 老化・配合 & 老 & 前 & 老化 & 後 & & \\
\hline 荷重・加 & $\cdots$ & $A-P$ & $B-P$ & $A-P$ & $\mathrm{~B}-\mathrm{P}$ & & \\
\hline $2.2 \mathrm{~kg}$ & $145^{\circ} \mathrm{C} \times 30$ 分 & 0.0027 & 0.0073 & 0.0033 & 0.0067 & $\mathrm{~B}$ & 社 \\
\hline $4.5 \mathrm{~kg}$ & $145^{\circ} \mathrm{C} \times 30$ 分 & 0.0132 & 0.0267 & 0.0218 & 0.0304 & & \\
\hline $6.8 \mathrm{~kg}$ & $145^{\circ} \mathrm{C} \times 30$ 分 & 0.0205 & 0.0408 & 0.0340 & 0.0516 & & \\
\hline $2.2 \mathrm{~kg}$ & $145^{\circ} \mathrm{C} \times 30$ 分 & 0.0068 & 0.0099 & 0.0067 & 0.0094 & I & 社 \\
\hline $4.5 \mathrm{~kg}$ & $145^{\circ} \mathrm{C} \times 30$ 分 & 0.0153 & 0.0227 & 0.0193 & 0.0279 & & \\
\hline $9.0 \mathrm{~kg}$ & $145^{\circ} \mathrm{C} \times 30$ 分 & 0.0305 & 0.0424 & 0.0361 & 0.0498 & & \\
\hline $4.0 \mathrm{~kg}$ & $145^{\circ} \mathrm{C} \times 30$ 分 & 0.0113 & 0.0175 & 0.0165 & 0.0282 & $G$ & 社 \\
\hline & $145^{\circ} \mathrm{C} \times 45$ 分 & 0.0104 & 0.0184 & 0.0202 & 0.0260 & & \\
\hline $4.5 \mathrm{~kg}$ & $145^{\circ} \mathrm{C} \times 30$ 分 & 0.0163 & 0.0236 & 0.0200 & 0.0284 & & \\
\hline & $145^{\circ} \mathrm{C} \times 45$ 分 & 0.0148 & 0.0244 & 0.0188 & 0.0366 & & \\
\hline $5.5 \mathrm{~kg}$ & $145^{\circ} \mathrm{C} \times 30$ 分 & 0.0375 & 0.0502 & 0.0263 & 0.0395 & & \\
\hline & $145^{\circ} \mathrm{C} \times 45$ 伃 & 0.0370 & 0.0477 & 0.0256 & 0.0383 & & \\
\hline
\end{tabular}


表6-2 ピコ摩耗試験結果：乘用車タイヤ トレッドより試料採取（B社）

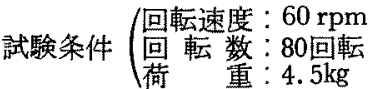
単位: cc

\begin{tabular}{|c|c|c|}
\hline $\begin{array}{ll} & \text { 配合 } \\
\text { 試料 }\end{array}$ & $A-P$ & $B-P$ \\
\hline 行 前 & $0.0167(101)$ & $0.0169(100)$ \\
\hline $\begin{array}{l}\text { 息路，走行後 } \\
(100 \% \text { 舖装) }\end{array}$ & $0.0145(108)$ & $0.0157(100)$ \\
\hline $\begin{array}{l}\text { 中間路走行後 } \\
(90 \% \text { 舗 装) }\end{array}$ & $0.0152(103)$ & $0.0157(100)$ \\
\hline $\begin{array}{l}\text { 恶路 走 行後 } \\
(70 \% \text { 舗 装) }\end{array}$ & $0.0139(104)$ & $0.0145(100)$ \\
\hline
\end{tabular}

\section{(LOSS:CO/BOREV.)}

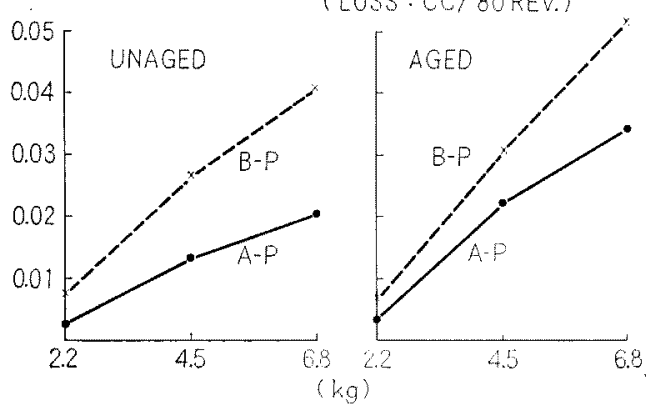

図5-(2) ピコ摩耗試験結果 : 乗用車用タイヤト レッド配合（I 社試験）

\section{(LOSS: CC/ 80REV.)}

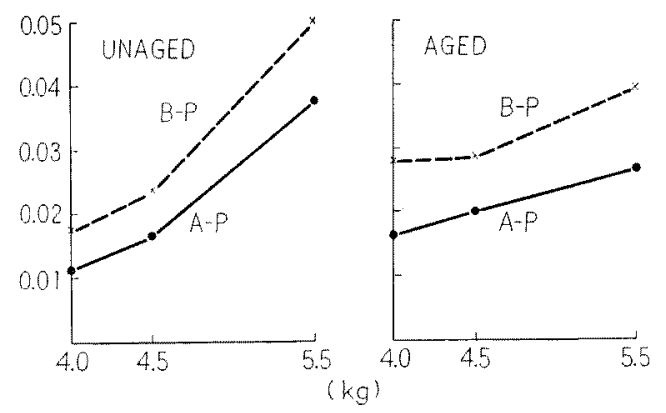

図5-(3) ピコ摩耗試験結果: 委用車用タイヤト レッド配合（G社試験）

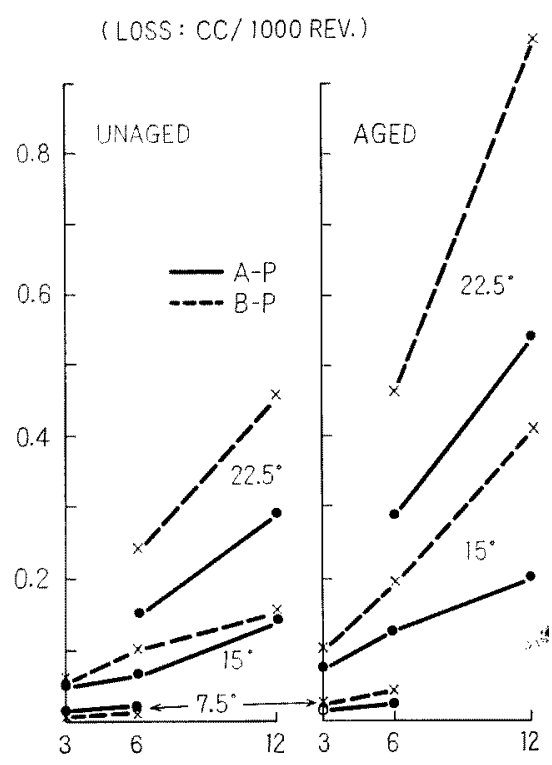

(lb)

図 6 アクロン摩耗試験結果 : 乗用車用タイヤ トレッド配合（I 社試験）

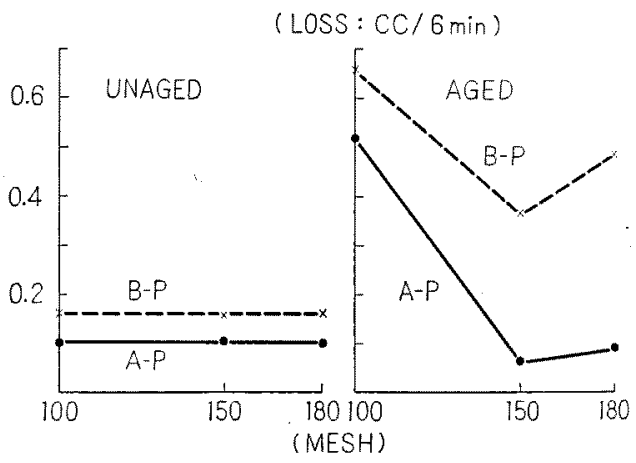

四 7 ウィリアムス摩耗試験結果 : 乗用車用夕 イヤトレッド配合（G社試験）

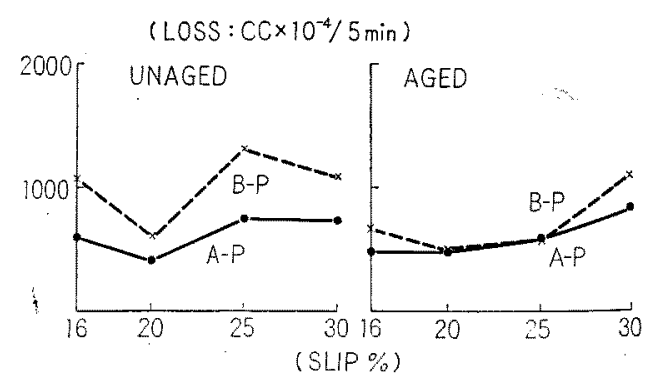

図 8 改良ランボーン摩耗試験結果 : 乘用車用 タイヤトレッド配合（H社試験） 
表 7 アクロン摩耗試験結果：乗用車用タイヤトレッド配合

单位: cc/mile

\begin{tabular}{|c|c|c|c|c|c|c|c|c|}
\hline \multirow{2}{*}{\multicolumn{2}{|c|}{ 角度 ·荷重 ・加硫 }} & \multirow{2}{*}{ 老化・配合 } & \multirow{2}{*}{$\frac{\text { t }}{\mathrm{A}-\mathrm{P}}$} & \multirow{2}{*}{ 前 } & \multicolumn{2}{|c|}{ 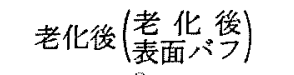 } & \multirow{2}{*}{\multicolumn{2}{|c|}{ 試験担当 }} \\
\hline & & & & & $A-P$ & $\mathbf{B}-\mathbf{P}$ & & \\
\hline \multirow{4}{*}{$7.5^{\circ}$} & $3 \mathrm{Ib}$ & $140^{\circ} \mathrm{C} \times 40$ 分 & 0.0100 & 0.0066 & 0.0117 & 0.0186 & \multirow{14}{*}{ I } & \multirow{14}{*}{ 社 } \\
\hline & & $140^{\circ} \mathrm{C} \times 60$ 分 & 0.0089 & 0.0048 & 0.0146 & 0.0178 & & \\
\hline & $6 \mathrm{lb}$ & $140^{\circ} \mathrm{C} \times 40$ 分 & 0.0166 & 0.0126 & 0.0224 & 0.0399 & & \\
\hline & & $140^{\circ} \mathrm{C} \times 60$ 分 & 0.0175 & 0.0126 & 0.0189 & 0.0270 & & \\
\hline \multirow{6}{*}{$15^{\circ}$} & $3 \mathrm{lb}$ & $140^{\circ} \mathrm{C} \times 40$ 分 & 0.0439 & 0.0522 & 0.0732 & 0.1005 & & \\
\hline & & $140^{\circ} \mathrm{C} \times 60$ 分 & 0.0451 & 0.0548 & 0.0715 & 0.1005 & & \\
\hline & $6 \mathrm{lb}$ & $140^{\circ} \mathrm{C} \times 40$ 分 & 0.0643 & 0.0905 & 0.1241 & 0.1954 & & \\
\hline & & $140^{\circ} \mathrm{C} \times 60$ 分 & 0.0643 & 0.0916 & 0.1295 & 0.1977 & & \\
\hline & $121 \mathrm{~b}$ & $140^{\circ} \mathrm{C} \times 40$ 分 & 0.1418 & 0.1487 & 0.1974 & 0.3816 & & \\
\hline & & $140^{\circ} \mathrm{C} \times 60$ 分 & 0.1333 & 0.1919 & 0.2258 & 0.3704 & & \\
\hline \multirow{4}{*}{$22.5^{\circ}$} & $6 \mathrm{lb}$ & $140^{\circ} \mathrm{C} \times 40$ 分 & 0.1551 & 0.2396 & 0.2643 & 0.4612 & & \\
\hline & & $140^{\circ} \mathrm{C} \times 60$ 分 & 0.1491 & 0.2629 & 0.2488 & 0.4488 & & \\
\hline & $12 \mathrm{lb}$ & $140^{\circ} \mathrm{C} \times 40$ 分 & 0.2902 & 0.4626 & 0.5431 & 0.9655 & & \\
\hline & & $140^{\circ} \mathrm{G} \times 60$ 分 & 0.2729 & 0.4589 & 0.4336 & 0.9339 & & \\
\hline & & & & & & & \multicolumn{2}{|c|}{ 单位：cc/1000回 } \\
\hline \multirow{2}{*}{$12.5^{\circ}$} & $6 \mathrm{lb}$ & $145^{\circ} \mathrm{C} \times 30$ 分 & 0.008 & 0.007 & 0.022 & 0.033 & \multirow{6}{*}{$\mathrm{G}$} & \multirow{6}{*}{ 社 } \\
\hline & & $145^{\circ} \mathrm{C} \times 45$ 分 & 0.007 & 0.003 & 0.021 & 0.024 & & \\
\hline \multirow{2}{*}{$15^{\circ}$} & $6 \mathrm{lb}$ & $145^{\circ} \mathrm{C} \times 305^{5}$ & 0.040 & 0.040 & 0.105 & 0.123 & & \\
\hline & & $145^{\circ} \mathrm{C} \times 45$ 分 & 0.032 & 0.041 & 0.101 & 0.121 & & \\
\hline \multirow{2}{*}{$17.5^{\circ}$} & $6 \mathrm{lb}$ & $145^{\circ} \mathrm{C} \times 30$ 分 & 0.129 & 0.174 & 0.187 & 0.238 & & \\
\hline & & $145^{\circ} \mathrm{C} \times 45$ 分 & 0.129 & 0.175 & 0.188 & 0.241 & & \\
\hline
\end{tabular}

表 8 ウイリアムス摩耗験験結果：乗用車用タイヤトレッド配合（G社）

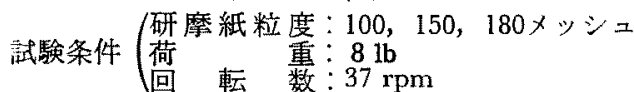

熱老化条件：100总 $\times 48 \mathrm{~h}$

単位: cc/6分間(試験数 $\mathrm{n}=2$ )

\begin{tabular}{|c|c|c|c|c|c|}
\hline \multirow[b]{2}{*}{ 研摩紙・加硫 } & \multirow{2}{*}{ 老化・配合 } & \multirow{2}{*}{$\frac{\text { tz }}{A-P}$} & \multirow{2}{*}{$\frac{\text { 前 }}{\text { B-P }}$} & \multicolumn{2}{|c|}{ 老化後(老表面バフ 後 $)$} \\
\hline & & & & $A-P$ & $B-P$ \\
\hline \multirow{2}{*}{\multicolumn{2}{|c|}{$100 \times ッ シ=\left\{\begin{array}{l}145^{\circ} \mathrm{C} \times 30 \text { 分 } \\
145^{\circ} \mathrm{C} \times 45 \text { 分 }\end{array}\right.$}} & 0.1034 & 0.1637 & 0.5149 & 0.6610 \\
\hline & & 0.1146 & 0.1921 & 0.1237 & 0.6555 \\
\hline \multirow{2}{*}{ 150メッシュ } & $145^{\circ} \mathrm{C} \times 30$ 分 & 0.1065 & 0.1578 & 0.0631 & 0.3674 \\
\hline & $145^{\circ} \mathrm{C} \times 45$ 分 & 0.1080 & 0.1786 & 0.1110 & 0.4177 \\
\hline \multirow{2}{*}{$180 x ッ シ ュ$} & $\int 145^{\circ} \mathrm{C} \times 30$ 分 & 0.0971 & 0.1593 & 0.0913 & 0.4868 \\
\hline & $145^{\circ} \mathrm{C} \times 45$ 分 & 0.1104 & 0.1683 & 0.0624 & 0.5386 \\
\hline
\end{tabular}


表 9 改良ランボーン摩耗試駼結果：乗用車用タイヤトレッド配合（H社）

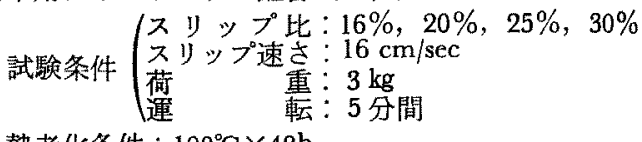

熱老化条件： $100^{\circ} \mathrm{G} \times 48 \mathrm{~h}$

単位: $c c \times 10^{-4}$ (試験数 $n=3$ )

\begin{tabular}{|c|c|c|c|c|c|c|}
\hline \multirow[b]{2}{*}{ スリップ比 } & \multicolumn{3}{|c|}{$A-P$} & \multicolumn{3}{|c|}{$B-P$} \\
\hline & 老化前 & $\begin{array}{l}\text { 予備すり後 } \\
\text { 老 }\end{array}$ & $\begin{array}{l}\text { 老化 後 } \\
\text { 予備すり }\end{array}$ & 老化前 & $\begin{array}{l}\text { 予備すり後 } \\
\text { 老 }\end{array}$ & $\begin{array}{l}\text { 老化後 } \\
\text { 予備与 }\end{array}$ \\
\hline $16 \%$ & 621 & 483 & 106 & 1,079 & 675 & 94 \\
\hline $20 \%$ & 422 & 485 & 167 & 607 & 482 & 110 \\
\hline $25 \%$ & 778 & 580 & 277 & 1,336 & 571 & 258 \\
\hline $30 \%$ & 736 & 837 & 161 & 1,093 & 1,108 & 138 \\
\hline
\end{tabular}

表10 ランボーン形摩耗試験結果：乗用事用タイヤトレッド配合（G社）

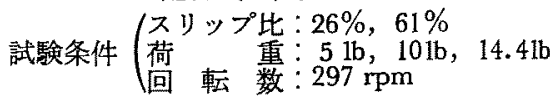

熱老化条件 : $100^{\circ} \mathrm{C} \times 48 \mathrm{~h}$ 単位: $\mathrm{cc} /$ 分( 試験数 $\mathrm{n}=2$ )

\begin{tabular}{|c|c|c|c|c|c|c|}
\hline \multirow{2}{*}{\multicolumn{3}{|c|}{ スリップ比・荷重・加硫 }} & \multirow{2}{*}{$\frac{\text { 老 }}{A-P}$} & \multirow{2}{*}{$\frac{\text { 前 }}{\mathbf{B}-\mathbf{P}}$} & \multicolumn{2}{|c|}{ 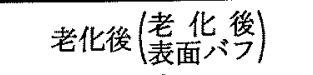 } \\
\hline & & & & & $A-P$ & $\mathrm{~B}-\mathrm{P}$ \\
\hline \multirow{6}{*}{$26 \%$} & $5 \mathrm{lb}$ & $145^{\circ} \mathrm{C} \times 30$ 分 & 0.011 & 0.017 & 0.106 & 0.115 \\
\hline & & $145^{\circ} \mathrm{C} \times 45$ 分 & 0.010 & 0.015 & 0.106 & 0.116 \\
\hline & $10 \mathrm{lb}$ & $145^{\circ} \mathrm{G} \times 30$ 分 & 0.035 & 0.048 & 0.161 & 0.177 \\
\hline & & $145^{\circ} \mathrm{C} \times 455^{\mathrm{J}}$ & 0.037 & 0.044 & 0.139 & 0.160 \\
\hline & $14.4 \mathrm{lb}$ & $145^{\circ} \mathrm{C} \times 30$ 分 & 0.068 & 0.076 & 0.148 & 0.163 \\
\hline & & $145^{\circ} \mathrm{C} \times 45$ 分 & 0.054 & 0.069 & 0.149 & 0.147 \\
\hline \multirow{6}{*}{$61 \%$} & $5 \mathrm{lb}$ & $145^{\circ} \mathrm{C} \times 30$ 分 & 0.044 & 0.076 & 0.148 & 0.163 \\
\hline & & $145^{\circ} \mathrm{G} \times 45$ 分 & 0.051 & 0.069 & 0.149 & 0.147 \\
\hline & $101 \mathrm{~b}$ & $145^{\circ} \mathrm{C} \times 30$ 分 & 0.175 & 0.258 & 0.322 & 0.379 \\
\hline & & $145^{\circ} \mathrm{C} \times 45$ 分 & 0.202 & 0.202 & 0.320 & 0.349 \\
\hline & $14.4 \mathrm{lb}$ & $145^{\circ} \mathrm{G} \times 30$ 分 & 0.383 & 0.527 & 0.399 & 0.696 \\
\hline & & $145^{\circ} \mathrm{C} \times 45$ 分 & 0.383 & 0.537 & 0.494 & 0.593 \\
\hline
\end{tabular}

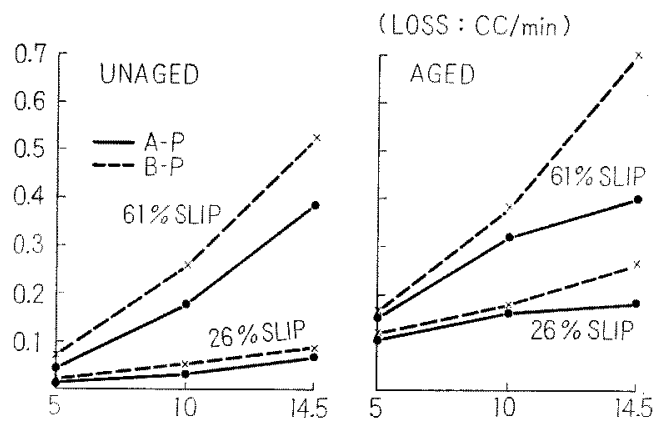

(lb)

図 9 ランボーン摩耗試験結果 : 乗用車用タ イヤトレッド配合（G社試験） 
表11 乗用車用タイヤトレッド配合物性試験（D社）

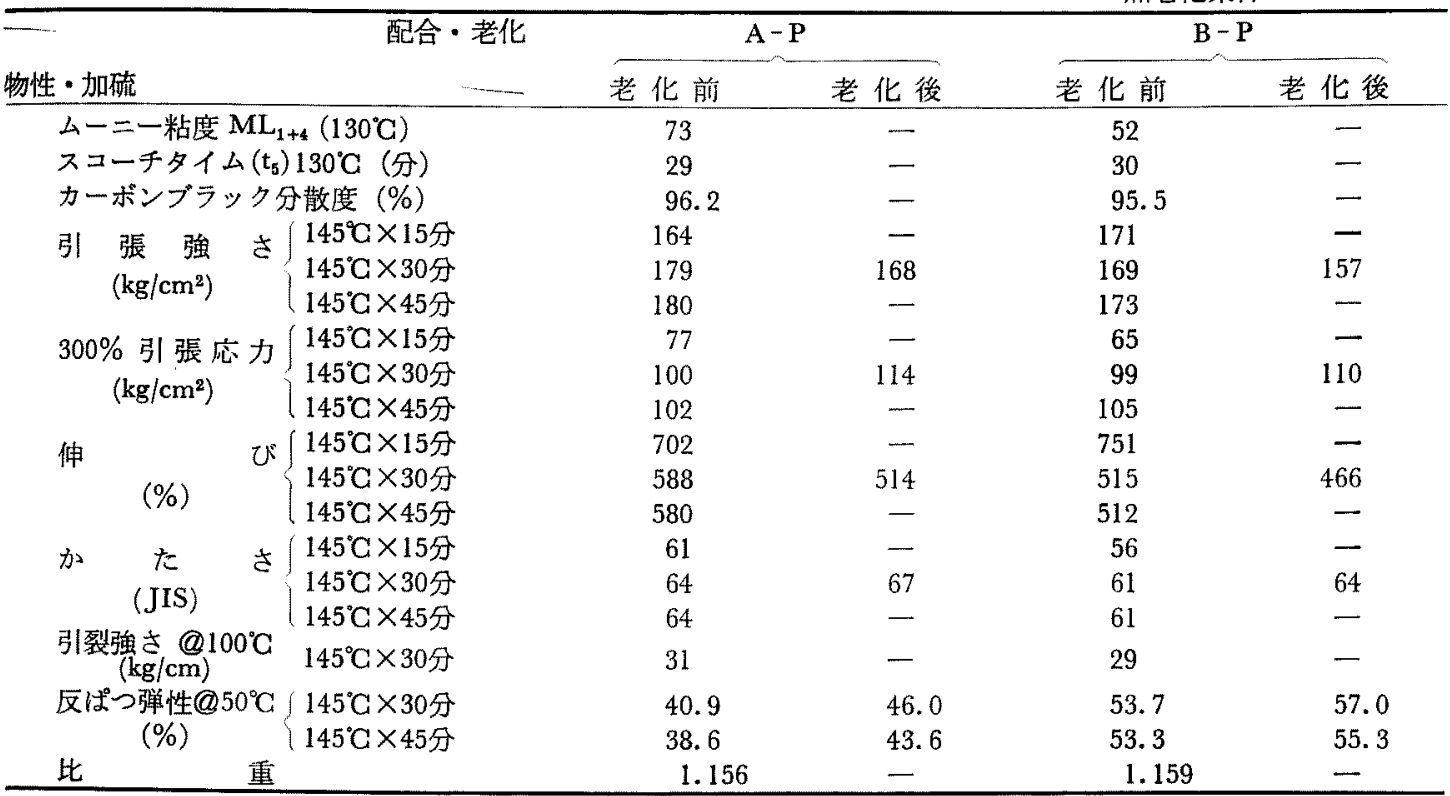

表12トラック用タイヤ実車走行試験結果：トレッドみぞ深さ测定（走行終了時）

(10.00-20 14PR HT-LUG 後輸 4 本テストタイヤ装着)

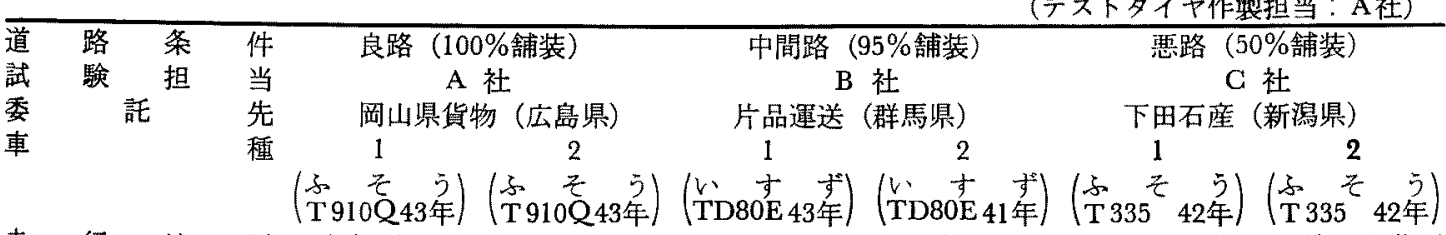
走行地区広島-大阪広島一大阪 沼田-東京-静岡沼田-春日井-富山新潟県南蒲原 新潟県南蒲原
77,180
79,030
47,750
41,260
21,520
18,260

走 行 距 離 $(\mathrm{km})$

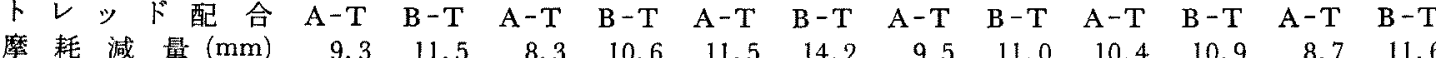

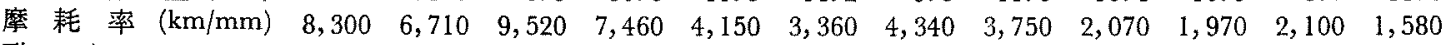

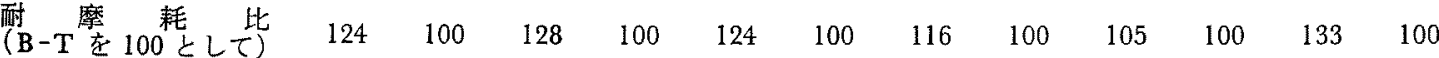

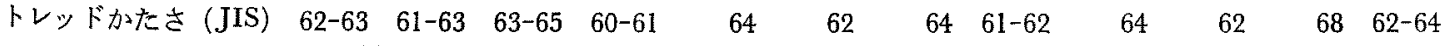

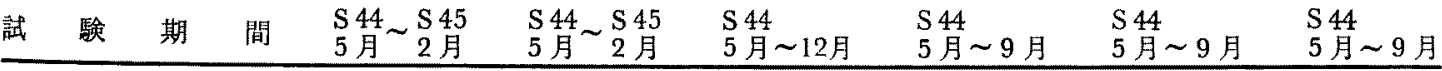
表13 トラック用タイヤ実車走行試験結果（走行距離ごとのトレッドみぞ深さ测定）（A社） (1) 良路 (100\%舖装) 岡山県貨物 (広島)

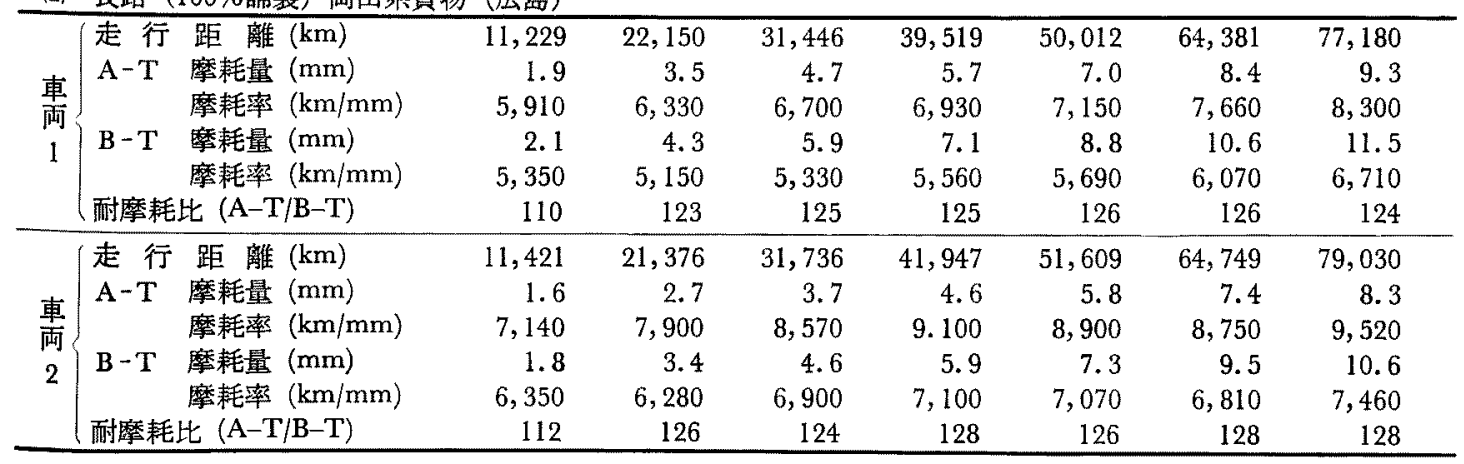

(99) 
自動車用夕イヤの摩耗

日本三ム協会站

（2）中間路 $(95 \%$ 舗装）片品運送（群馬）（B社）

\begin{tabular}{|c|c|c|c|c|c|}
\hline 車両 1 & $\begin{array}{ll}\text { 走 行 } & \text { 距 離 }(\mathrm{km}) \\
\mathrm{A}-\mathrm{T} & \text { 摩耗量 }(\mathrm{mm}) \\
& \text { 摩耗率 }(\mathrm{km} / \mathrm{mm}) \\
\mathrm{B}-\mathrm{T} & \text { 摩耗量 }(\mathrm{mm}) \\
& \text { 摩耗率 }(\mathrm{km} / \mathrm{mm}) \\
\text { 酎摩耗比 }(\mathrm{A}-\mathrm{T} / \mathrm{B}-\mathrm{T})\end{array}$ & $\begin{array}{r}7,794 \\
2.3 \\
3,390 \\
2.6 \\
3,000 \\
113\end{array}$ & $\begin{array}{r}18,885 \\
4.8 \\
3,930 \\
5.9 \\
3,200 \\
123\end{array}$ & $\begin{array}{r}36,285 \\
8.4 \\
4,230 \\
10.4 \\
3,490 \\
124\end{array}$ & $\begin{array}{r}47,750 \\
11.5 \\
4,150 \\
14.2 \\
3,360 \\
124\end{array}$ \\
\hline 車雨 2 & $\begin{cases}\text { 走 行 距 離 }(\mathrm{km}) \\
\mathrm{A}-\mathrm{T} & \text { 摩耗量 }(\mathrm{mm}) \\
& \text { 摩耗率 }(\mathrm{km} / \mathrm{mm}) \\
\mathrm{B}-\mathrm{T} & \text { 摩耗量 }(\mathrm{mm}) \\
& \text { 摩耗率 }(\mathrm{km} / \mathrm{mm}) \\
\text { 耐摩耗比 }(\mathrm{A}-\mathrm{T} / \mathrm{B}-\mathrm{T})\end{cases}$ & $\begin{array}{r}10,416 \\
2.6 \\
4,000 \\
3.3 \\
3,150 \\
127\end{array}$ & $\begin{array}{r}23,690 \\
5.8 \\
4,080 \\
7.1 \\
3,340 \\
122\end{array}$ & $\begin{array}{r}41,260 \\
9.5 \\
4,340 \\
11.0 \\
3,750 \\
116\end{array}$ & $\begin{array}{l}- \\
- \\
- \\
-\end{array}$ \\
\hline
\end{tabular}

（3）悪路（50\%舗装）下田石産（新潟）（G社）

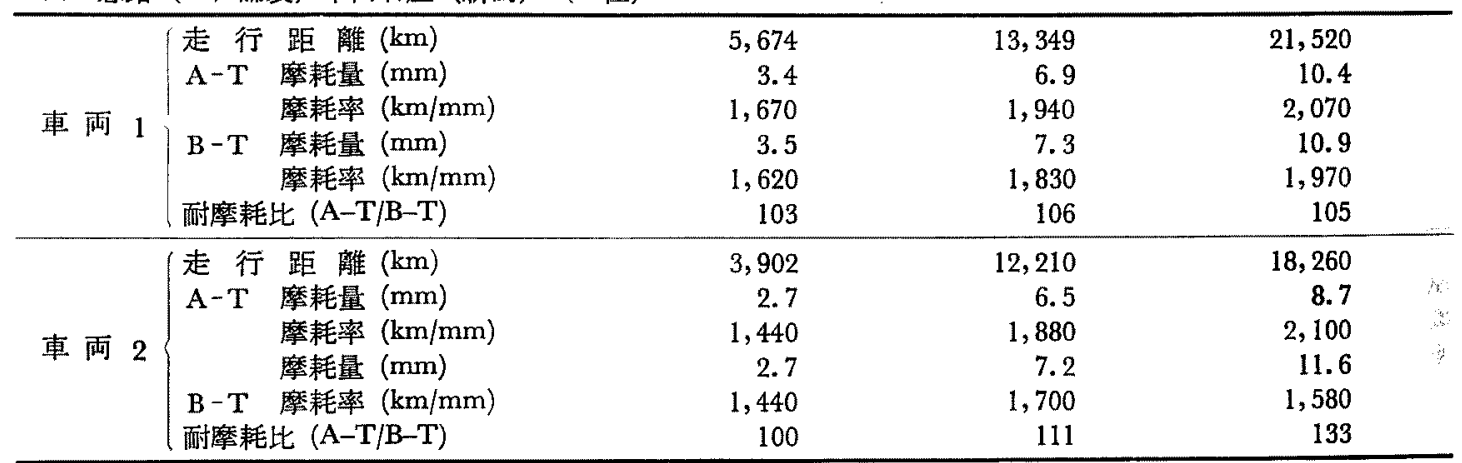

表14トラック用タイヤ実車走行試験結果：タイヤ重量測定（走行終了時）

(10.00-20 14PR HT-LUG 後輪 4 本テストタイヤ装着)（テストタイヤ作製担当：A社）

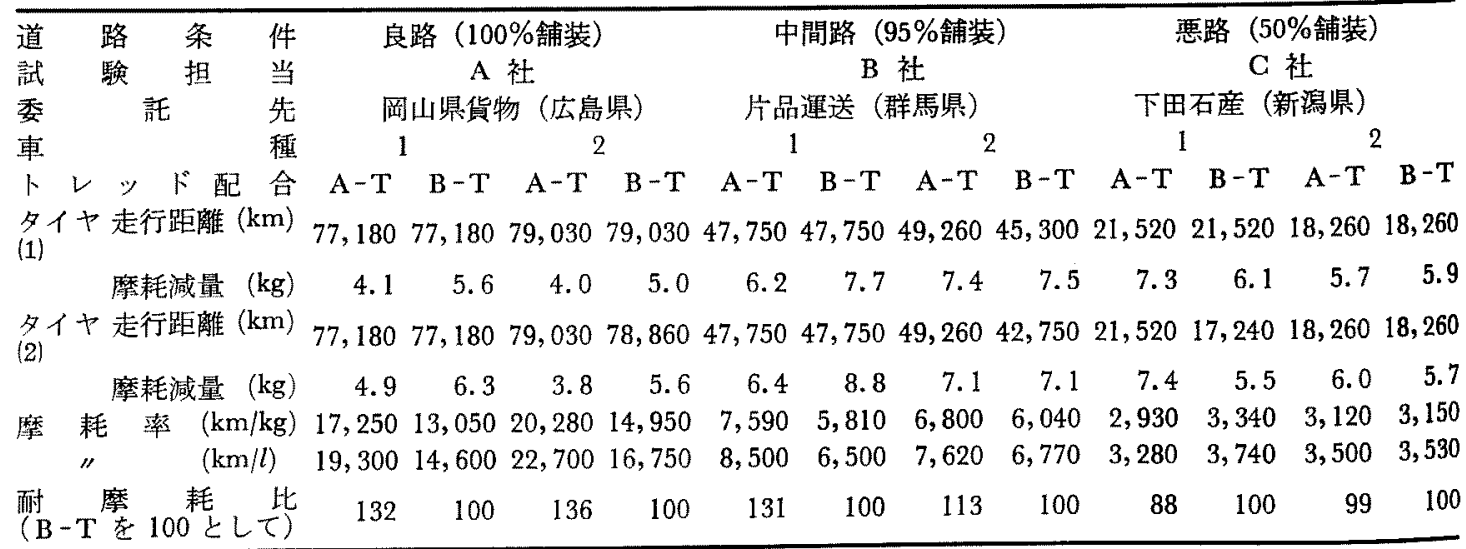



山本博美

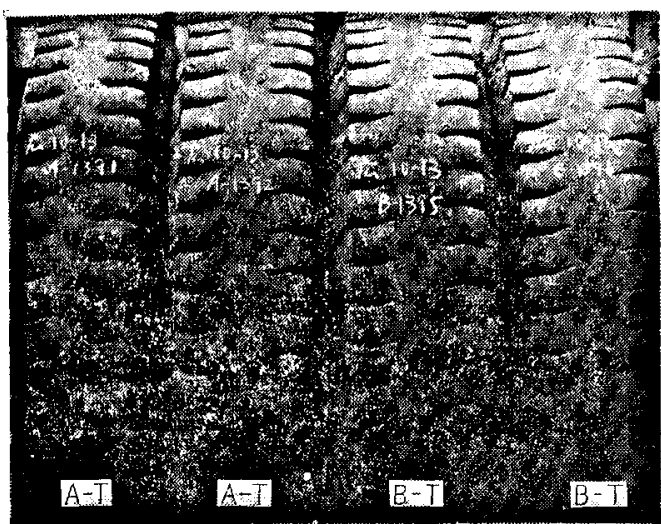

(1) 良路 (100\%舖装) - 岡山県貨物（試験担当： $A$ 社） 車 種 1

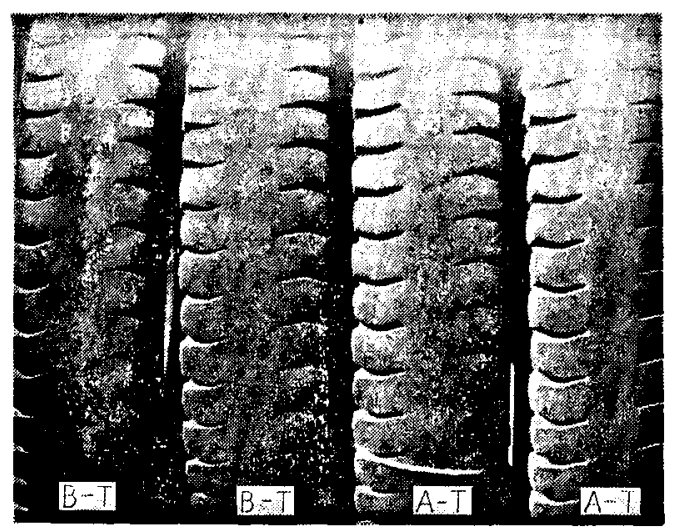

(2) 中間路 (95\%埔装) - 片品運送（試験担当：B 社） 車 種 1

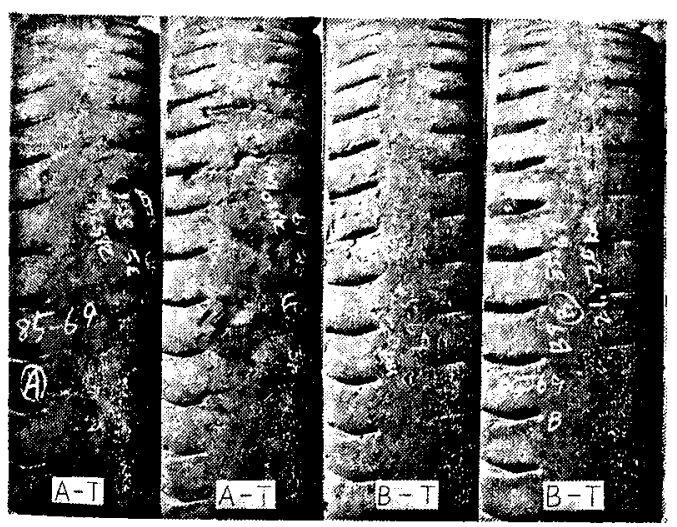

(3) 悪路 ( $50 \%$ 舗装) -下田石産（試験担当：C社) 車 種 1

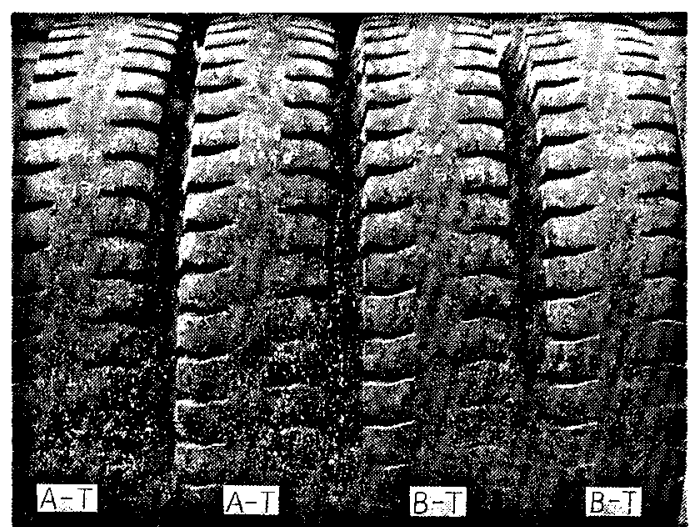

車 種 2

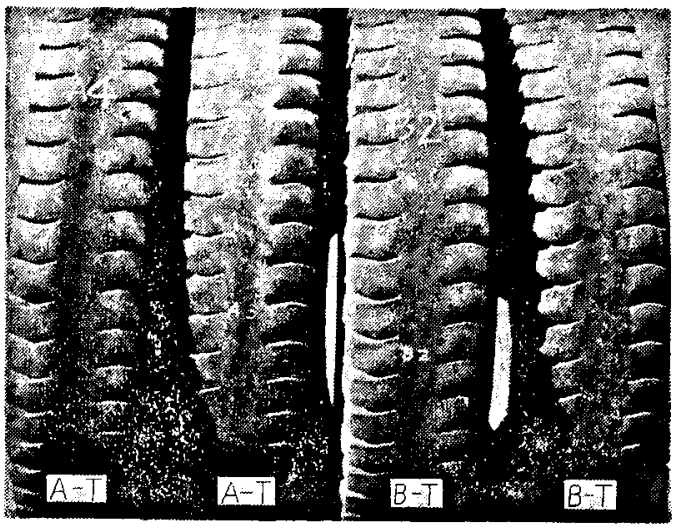

車 種 2

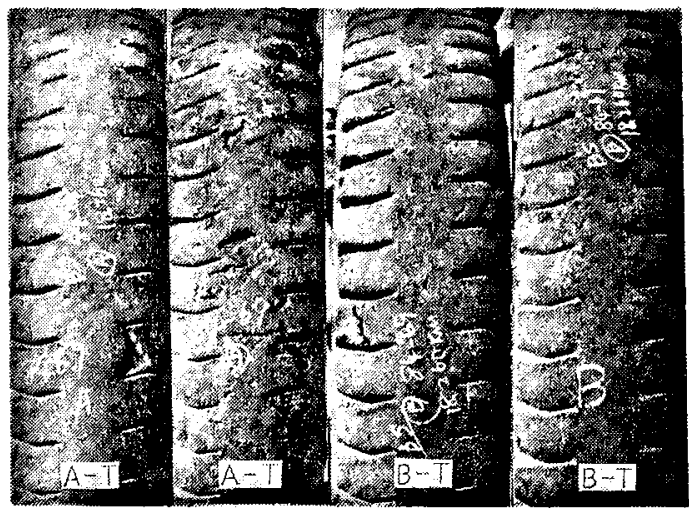

車 種 2

図10 トラック用タイヤ実車走行試験終了タイヤ 
表15 乘用車用タイヤ実車走行試験結果：トレッドみぞ深さ測定（走行終了時）

(5.60-13 4PR 後輸 2 本テストタイヤ装着)（テストタイヤ作製担当：D社）

第 1 次試験

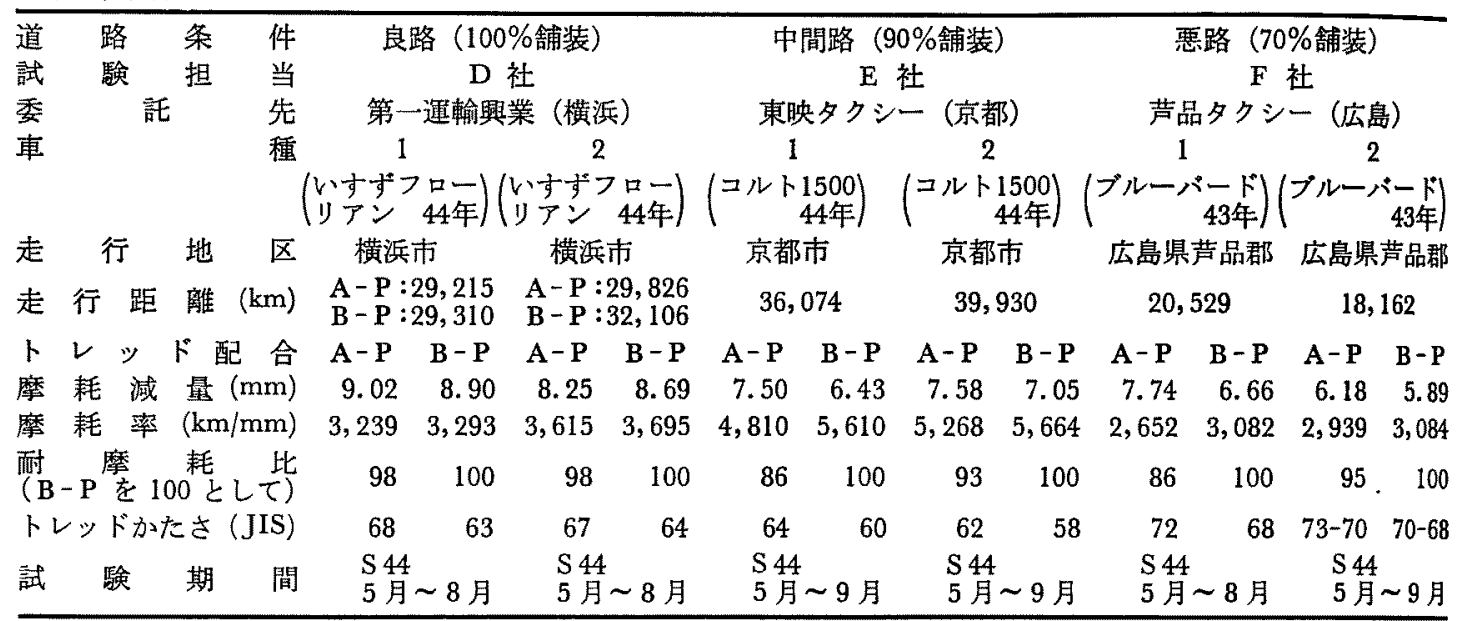

第 2 次試験（トレッドみぞ哚さ測定）

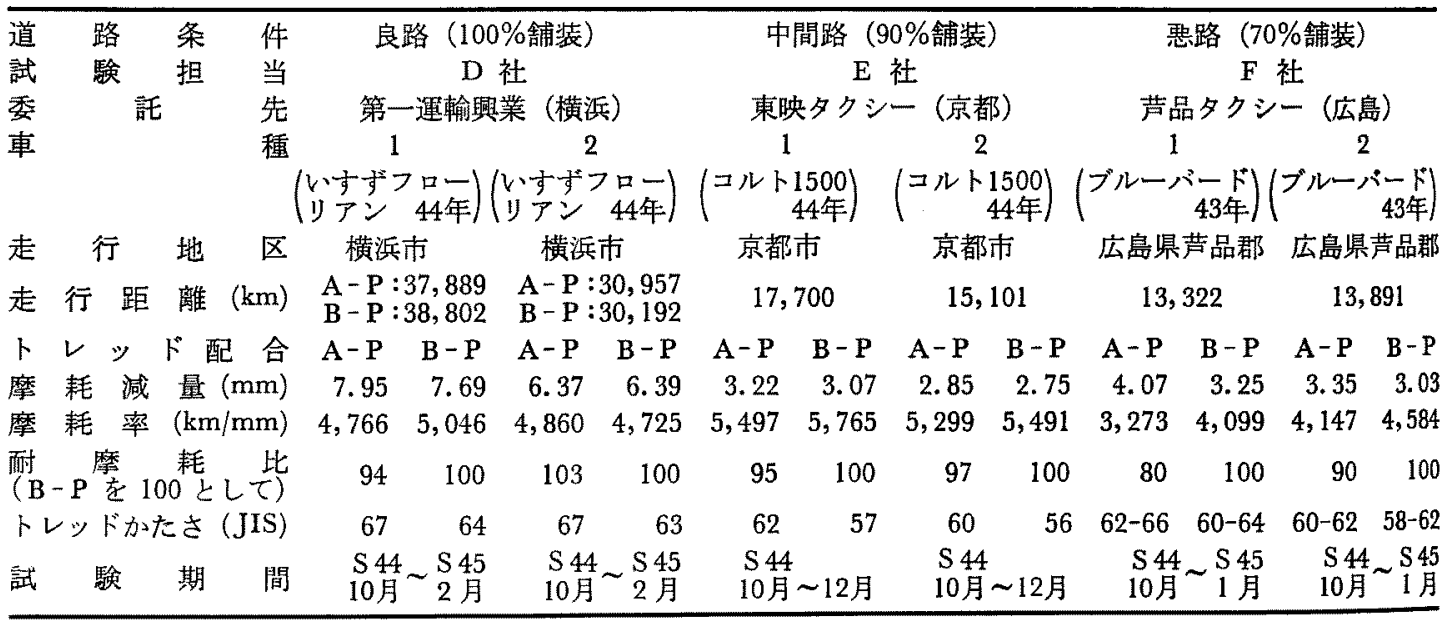

表16-1 乗用車用タイヤ実車走行試験結果（走行距離ごとのトレッドみぞ深さ測定） （1-1）良路 (100\%舗装) 第 1 次試験・第一運輸興業（横浜）（D社）

\begin{tabular}{|c|c|c|c|c|c|c|c|}
\hline \multirow{6}{*}{$\begin{array}{c}\frac{\text { 車 }}{\text { 两 }} \\
1\end{array}$} & 走 行 距 離 $(\mathrm{km})$ & 5,275 & 11,335 & 15,388 & 19.581 & 24,910 & $\begin{array}{l}\text { A }: 29,215 \\
\text { B }: 29,310\end{array}$ \\
\hline & $\mathrm{A}-\mathrm{P}$ 摩耗量 $(\mathrm{mm})$ & 2.6 & 4.3 & 5.6 & 6.6 & 8.2 & 9.0 \\
\hline & 摩耗率 $(\mathrm{km} / \mathrm{mm})$ & 2,029 & 2,636 & 2,748 & 2,967 & 3,038 & 3,239 \\
\hline & B-P 摩耗量 (mm) & 2.4 & 4.1 & 5.4 & 6.5 & 8.0 & 8.9 \\
\hline & 摩耗率 $(\mathrm{km} / \mathrm{mm})$ & 2,198 & 2,765 & 2,850 & 3,012 & 3,114 & 3,293 \\
\hline & 耐摩耗比 $(\mathrm{A}-\mathrm{P} / \mathrm{B}-\mathrm{P})$ & 92 & 95 & 96 & 99 & 98 & 98 \\
\hline \multirow{6}{*}{$\begin{array}{c}\text { 車 } \\
\text { 両 } \\
2\end{array}$} & 走 行 距 離 $(\mathrm{km})$ & 4,851 & 10,333 & 14,623 & 18,303 & 23,058 & $\begin{array}{l}\text { A : }: 29,826 \\
\text { B : } 32,106\end{array}$ \\
\hline & $A-P$ 摩耗量 $(\mathrm{mm})$ & 2.3 & 3.7 & 5.0 & 5.9 & 7.2 & 8.3 \\
\hline & 摩耗率 $(\mathrm{km} / \mathrm{mm})$ & 2,109 & 2,793 & 2,925 & 3,102 & 3,203 & 3,615 \\
\hline & $\mathrm{B}-\mathrm{P}$ 摩耗量 $(\mathrm{mm})$ & 2.0 & 3.5 & 4.7 & 5.4 & 6.6 & 8.7 \\
\hline & 摩耗率 $(\mathrm{km} / \mathrm{mm})$ & 2,426 & 2,952 & 3,111 & 3,389 & 3,494 & 3,695 \\
\hline & 耐摩耗比 $(\mathrm{A}-\mathrm{P} / \mathrm{B}-\mathrm{P})$ & 87 & 95 & 94 & 92 & 92 & 97 \\
\hline
\end{tabular}


第44巻 第 2 号 (1971)

山本博美

\begin{tabular}{|c|c|c|c|c|c|c|}
\hline$(1-2$ & 2) 良路（100\%㦸装）第 2 & 第一運輸興業 & （横浜） & (D社) & & \\
\hline \multirow{6}{*}{$\begin{array}{c}\text { 車 } \\
\text { 两 } \\
1\end{array}$} & 走 行 距 離 $(\mathrm{km})$ & 5,550 & 7,668 & 13,550 & 27,280 & $\begin{array}{l}\text { A : } 37,889 \\
\text { B : } 38,802\end{array}$ \\
\hline & A-P 摩耗量 (mm) & 2.0 & 2.5 & 4.0 & 5.6 & 8.0 \\
\hline & 摩耗率 $(\mathrm{km} / \mathrm{mm})$ & 2,775 & 3,067 & 3,388 & 4,871 & 4,766 \\
\hline & B-P 摩耗量 (mm) & 1.8 & 2.6 & 3.6 & 5.6 & 7.7 \\
\hline & 摩耗率 $(\mathrm{km} / \mathrm{mm})$ & 3,083 & 2,949 & 3,764 & 4,871 & 5,046 \\
\hline & 耐摩耗比 (A-P/B-P) & 90 & 104 & 90 & 100 & 94 \\
\hline \multirow{6}{*}{$\begin{array}{c}\text { 車 } \\
\text { 再 } \\
2\end{array}$} & 走 行 距 離 $(\mathrm{km})$ & 3,969 & 8,767 & 12,846 & 21,708 & $\begin{array}{l}\mathrm{A}: 30,957 \\
\mathrm{~B}: 30,192\end{array}$ \\
\hline & A-P 摩耗量 (mm) & 1.4 & 2.6 & 3.5 & 5.1 & 6.4 \\
\hline & 摩耗率 $(\mathrm{km} / \mathrm{mm})$ & 2,835 & 3,372 & 3,670 & 4,256 & 4,860 \\
\hline & B-P 糜耗量 (mm) & 1.3 & 2.5 & 3.3 & 4.7 & 6.4 \\
\hline & 摩耗率 $(\mathrm{km} / \mathrm{mm})$ & 3,053 & 3,507 & 3,893 & 4,619 & 4,725 \\
\hline & 耐摩耗比 (A-P/B-P) & 93 & 96 & 94 & 92 & 103 \\
\hline
\end{tabular}

（2-1）中間路（90\%赤装）・第1 次試験・東映タクシー（京都）（E社）

\begin{tabular}{|c|c|c|c|c|c|c|c|c|}
\hline \multirow{6}{*}{$\begin{array}{c}\text { 車 } \\
\text { 两 } \\
1\end{array}$} & (走 行 距 離 $(\mathrm{km})$ & 4,957 & 10,563 & 15,453 & 19,332 & 25,523 & 30,307 & 36,074 \\
\hline & $\mathbf{A}-\mathbf{P}$ 摩耗量 (mm) & 1.5 & 2.7 & 3.6 & 4.2 & 5.4 & 6.5 & 7.5 \\
\hline & 摩耗率 $(\mathrm{km} / \mathrm{mm})$ & 3,305 & 3,912 & 4,293 & 4,603 & 4,726 & 4,663 & 4,810 \\
\hline & B - P 摩耗量 (mm) & 1.3 & 2.6 & 3.5 & 4. 2 & 4.9 & 5.7 & 6.4 \\
\hline & 摩耗率 $(\mathrm{km} / \mathrm{mm})$ & 3,813 & 4,063 & 4,415 & 4,603 & 5,209 & 5,317 & 5,610 \\
\hline & 耐摩耗比 (A-P/B-P) & 87 & 96 & 97 & 100 & 91 & 88 & 86 \\
\hline \multirow{6}{*}{$\begin{array}{c}\text { 車 } \\
\text { 両 } \\
2\end{array}$} & (走 行 距 離 $(\mathrm{km})$ & 5,720 & 10,839 & 16,519 & 21,629 & 26,005 & 29,954 & 39,930 \\
\hline & A-P 摩耗量 (mm) & 1.6 & 2.9 & 3.8 & 4.8 & 5.3 & 5.9 & 7.6 \\
\hline & 摩耗率 $(\mathrm{km} / \mathrm{mm})$ & 3,575 & 3,738 & 4,347 & 4,519 & 4,907 & 5,077 & 5,268 \\
\hline & B-P 摩耗量 (mm) & 1.5 & 2.4 & 3.2 & 4.0 & 4.7 & 5.4 & 7.1 \\
\hline & 摩耗率 $(\mathrm{km} / \mathrm{mm})$ & 3,813 & 4,516 & 5,162 & 5,423 & 5,533 & 5,547 & 5,664 \\
\hline & 耐摩耗比 (A-P/B-P) & 94 & 83 & 84 & 83 & 89 & 92 & 93 \\
\hline
\end{tabular}

（2-2）中間路 (90\%舗装) 第 2 次試験・東映タクシー (京都) (E 社)

\begin{tabular}{|c|c|c|c|c|}
\hline 車 両 1 & $\begin{cases}\text { 走 行 } & \text { 距 離 }(\mathrm{km}) \\
\mathrm{A}-\mathrm{P} & \text { 摩耗量 }(\mathrm{mm}) \\
& \text { 摩耗率 }(\mathrm{km} / \mathrm{mm}) \\
\mathrm{B}-\mathrm{P} & \text { 摩耗量 }(\mathrm{mm}) \\
& \text { 摩耗率 }(\mathrm{km} / \mathrm{mm}) \\
\text { 耐摩耗比 }(\mathrm{A}-\mathrm{P} / \mathrm{B}-\mathrm{P})\end{cases}$ & $\begin{array}{r}5,328 \\
2.1 \\
2,537 \\
2.1 \\
2,664 \\
95\end{array}$ & $\begin{array}{r}10,428 \\
2.6 \\
4,011 \\
2.5 \\
4,171 \\
96\end{array}$ & $\begin{array}{r}17,700 \\
3.2 \\
5,497 \\
3.1 \\
5,765 \\
95\end{array}$ \\
\hline 車雨 2 & $\begin{cases}\text { 走 行 } \text { 距 離 }(\mathrm{km}) \\
\mathrm{A}-\mathrm{P} & \text { 摩耗量 }(\mathrm{mm}) \\
& \text { 摩耗率 }(\mathrm{km} / \mathrm{mm}) \\
\mathrm{B}-\mathrm{P} & \text { 摩耗量 }(\mathrm{mm}) \\
& \text { 摩耗率 }(\mathrm{km} / \mathrm{mm}) \\
\text { 耐摩耗比 }(\mathrm{A}-\mathrm{P} / \mathrm{B}-\mathrm{P})\end{cases}$ & $\begin{array}{r}5,406 \\
1.6 \\
3,379 \\
1.8 \\
3,003 \\
113\end{array}$ & $\begin{array}{r}9,832 \\
2.2 \\
4,469 \\
2.1 \\
4,682 \\
95\end{array}$ & $\begin{array}{r}15,101 \\
2.9 \\
5,299 \\
2.8 \\
5,491 \\
97\end{array}$ \\
\hline
\end{tabular}


（3-1）悪路 (70\%舗装) 第 1 次試験・芦品タクシー（広島）(F社）

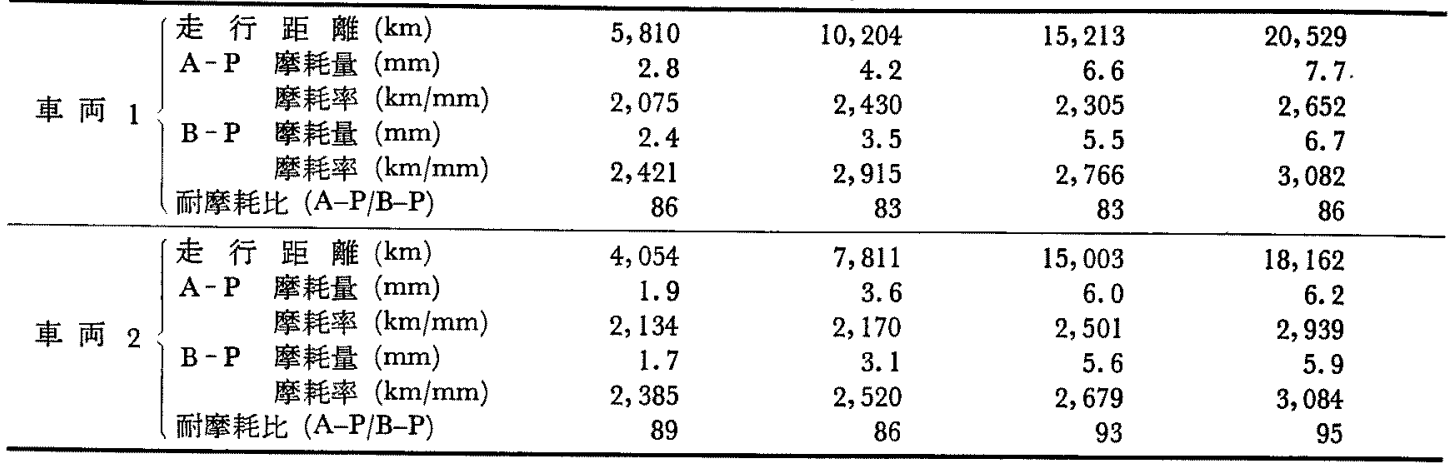

（3-2）覀路（70\%鍸装）第 2 次試験・芦品タタシー（広島）（F社）

\begin{tabular}{|c|c|c|c|c|}
\hline 車 雨 1 & $\begin{array}{ll}\text { 走 行 距 離 }(\mathrm{km}) \\
\mathrm{A}-\mathrm{P} & \text { 摩耗量 }(\mathrm{mm}) \\
& \text { 摩耗率 }(\mathrm{km} / \mathrm{mm}) \\
\mathrm{B}-\mathrm{P} & \text { 摩耗量 }(\mathrm{mm}) \\
& \text { 摩耗率 }(\mathrm{km} / \mathrm{mm}) \\
\text { 耐摩耗比 }(\mathrm{A}-\mathrm{P} / \mathrm{B}-\mathrm{P})\end{array}$ & $\begin{array}{r}4,539 \\
1.7 \\
2,670 \\
1.8 \\
2,522 \\
106\end{array}$ & $\begin{array}{r}9,599 \\
3.6 \\
2,666 \\
2.9 \\
3,310 \\
81\end{array}$ & $\begin{array}{r}13,322 \\
4.1 \\
3,273 \\
3.3 \\
4,099 \\
80\end{array}$ \\
\hline 車 両 2 & $\begin{array}{ll}\text { 走 行 } & \text { 距 離 }(\mathrm{km}) \\
\mathrm{A}-\mathrm{P} & \text { 摩耗量 }(\mathrm{mm}) \\
& \text { 摩耗率 }(\mathrm{km} / \mathrm{mm}) \\
\mathrm{B}-\mathrm{P} & \text { 摩耗量 }(\mathrm{mm}) \\
& \text { 摩耗率 }(\mathrm{km} / \mathrm{mm}) \\
\text { 耐摩耗比 }(\mathrm{A}-\mathrm{P} / \mathrm{B}-\mathrm{P})\end{array}$ & $\begin{array}{r}5,250 \\
1.7 \\
3,088 \\
2.0 \\
2,625 \\
118\end{array}$ & $\begin{array}{r}9,960 \\
3.2 \\
3,113 \\
2.9 \\
3,434 \\
91\end{array}$ & $\begin{array}{r}13,891 \\
3.4 \\
4,147 \\
3.0 \\
4,584 \\
90\end{array}$ \\
\hline
\end{tabular}

表17 乗用莗用タイヤ実車走行試験結果：タイヤ重量測定（走行終了時）

第 1 次試験

(5.60-13 4PR テストタイヤ後輪 2 本装着)

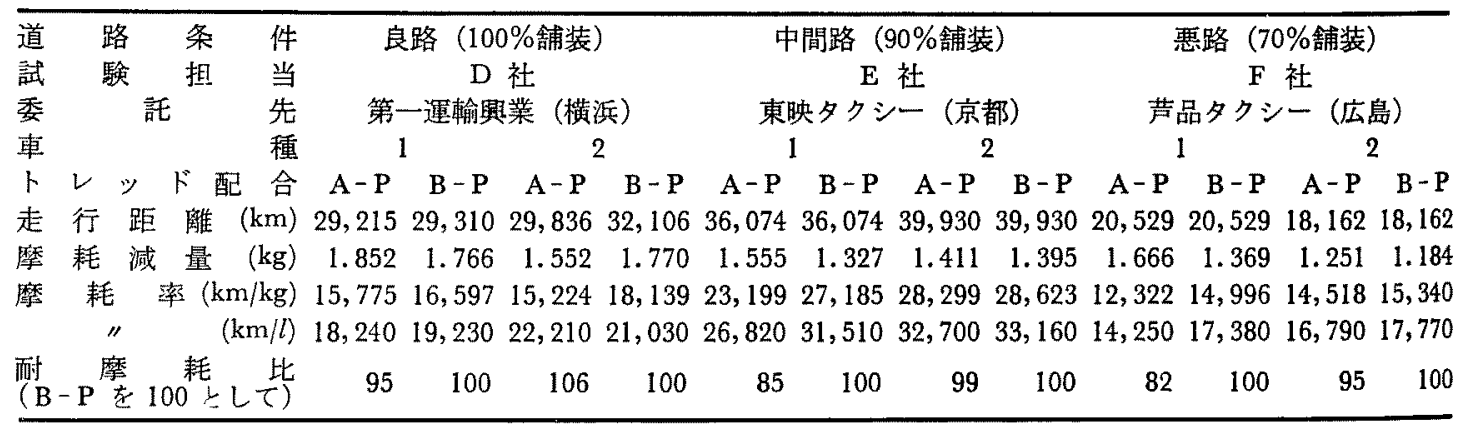

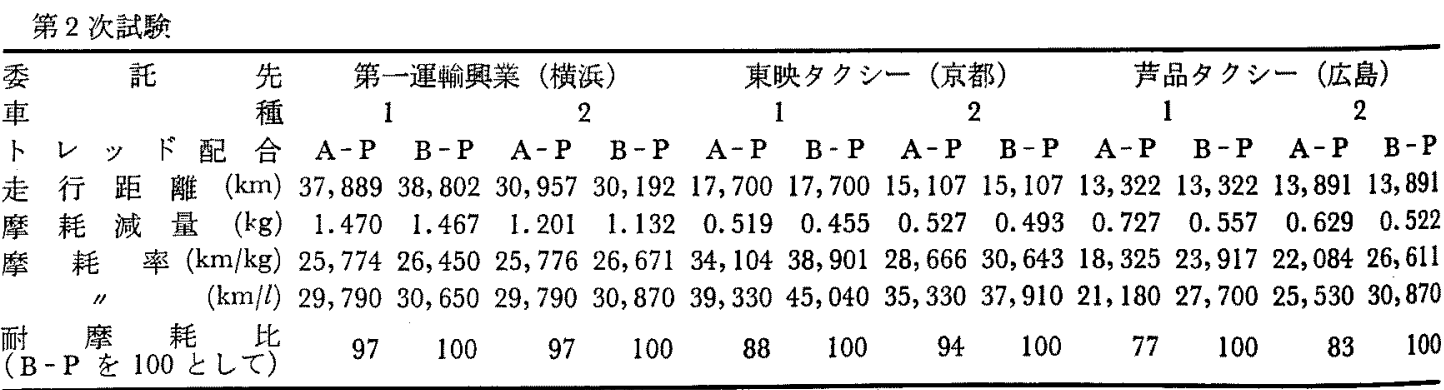




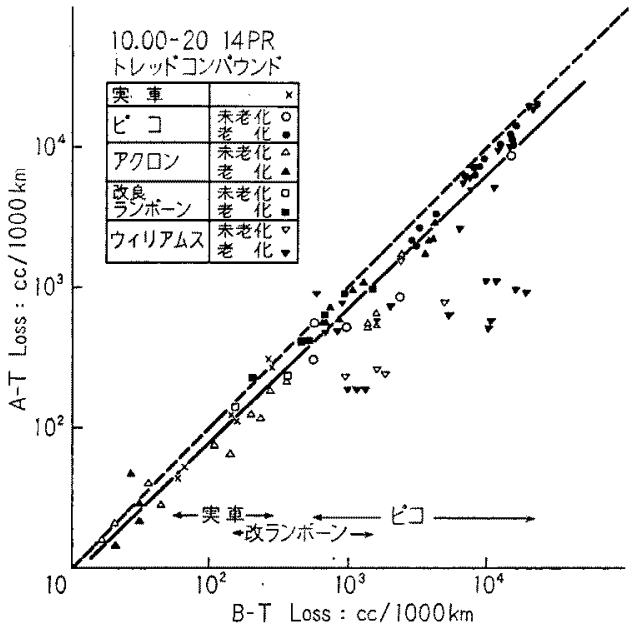

図11-(1) 摩耗と過酷度の関倸 (トラック用タイヤトレッド)

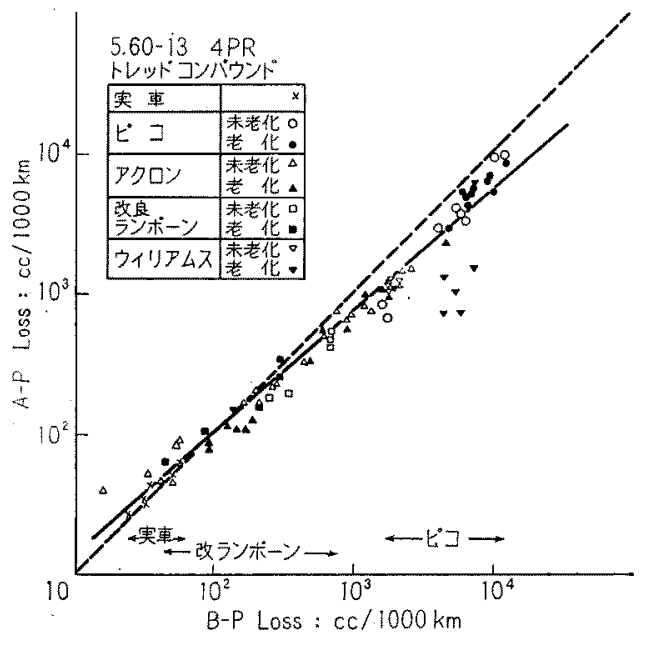

図11-(2) 摩耗と過酷度の関係

（乗用車用タイヤトレッド）

\section{4. 考察}

害験室試験と実車走行試験との関連について，今回の 試験結果から種々の検討を試みたが，タイヤの摩耗に は,トレッド配合やタイヤ構造などの内的因子のほかに タイヤの使用条件や動力学的要因など多くの外的因子が 複雑に影響を及ぼすので，現段階で摩耗機構に関する定 量的な結論を尊くことが困難であり，次のように定性的 な考察を述べることにとど主った。

(1) トラック用タイヤの実車走行試験結果では，A-T 配合トレッドが B-T 配合トレッドよりも，平均で $20 \%$
程度耐摩耗性が良好であった。これに対し，奏験室摩耗 試験結果も全般に各試験機とも A-T 配合が B-T 配合よ りも摩耗量が少ない成續であった。

良路拉よび中間路走行では，トレッド摩耗面はきわめ て円滑で, みぞ哚さ測定による哚度法と，タイヤ重量測定 による重量法とはほとんど類似の A-T/B-Tトレッド配 合耐摩耗比率を示した．悪路過酷条件の走行で A-T 配 合トレッドは供試ポリマーの影響などにより，トレッド チッピングを生じたため, 重量法摩耗量では B-T 配合 トレッドのほうが良好な耐摩耗比率を示した。

（2）乗用車用タイヤの実車走行試験の場合は，A-P 配 合トレッドのほうが B-P 配合トレッドよりも，やや摩 耗量が多い成績となった。これに対して実験室摩耗訟験 結果では，一部の低過酷度領域の試験を除いて，全体に A-P 配合が摩耗量が少なくなっている。

（3）全般にみて実莗走行摩耗に比し，実験空摩耗詿験 結果はテスト配合の耐摩耗比率が拡大されている倾向が あり，試験条件が過酷なほどこの傾向を示している。

物性試験結果と摩耗試験結果については，特に顕著な 相関は認められがたい，

(4) 実車走行摩耗と実験空試験機摩耗の関連につい て，摩耗の過酷度という考え方を用い，摩耗試験結果を 同一走行距離 $(1,000 \mathrm{~km})$ の摩耗損失とい5同一尺度 で，両対数グラフにプロットすると，図11に示したよう に奉車走行試験および実験室各種摩耗試験機を問わず， 直線となることが判明した，ただウイリアムス摩耗試験 による結果はこの直線から大幅にはずれ，タイヤ摩耗の 点では好ましくないと思われる。また，この試験条件の 過酷度からは，改良ランボーン摩耗試験機が，実車走行 の過酷度に近い領域にあったが，一般に実験室摩耗試験 機は実車走行よりも高過酷度領城になっている。

トラック用タイヤトレッド配合の場合，実車および武 験室での摩耗結果ともA-T 配合が，B-T 配合より耐摩 耗性がすぐれ，したがって過酷度の高い試験室の結果 で，両配合の赛車での摩耗性を比較することができる。 しかし，乘用車用タイヤトレッド配合の場合には，過酷 度が $10^{2}$ (Loss cc/1,000 km) 以下で実験室と実草走行の 両配合の酎摩耗性は逆転して，過酷度の高い試験空の結 果では実車走行の耐摩耗性を比較することはできない．

どのような配合の場合に，このような差がでるかは本 試験のみではわからない。これらの結果から奏験室で過 酷度の異なる試馱機あるいは試馱条件を任意に選択して 試験を行ない，その結果を図11のようにプロットして值 線を外そうすることにより，低過酷度に招ける摩耗（実 
車走行時の摩耗) の推定が可能であろうと考えられる。

(5)電子顕微鏡（レプリカ法）により摩耗面について 観察したところ，一般に実車走行による摩耗面の凹凸の 大きさはかなり小さい，凹凸の大きさや形から見て実験 室の摩耗面で，実車に最も類似していると思われるのは ピコ摩耗面である．またピコ摩耗面は本実験の範囲の過 酷度変化によって摩耗面はあまり変っていないが，アク ロン，改良ランボーンおよびウイリアムス試験機による 摩耗面は，各の過酷度の変化によって凹凸の大きさや形 状は著しく変化し，実車走行摩耗面に比してかなり凹凹 が大きい.

したがって定性的に摩耗現象だけ見れば，タイヤの実 車走行時における摩耗はピコ摩耗試験機のような把り起 こし機構によるものが支配的ではないかと考えられる。

\section{5. 結 論}

トラック用タイヤについては，ポリマーおよびカーポ ンの配合差から総合的に予測どおりの試駼成績を得た が，乗用車用タイヤについては，実車走行成績が微小な

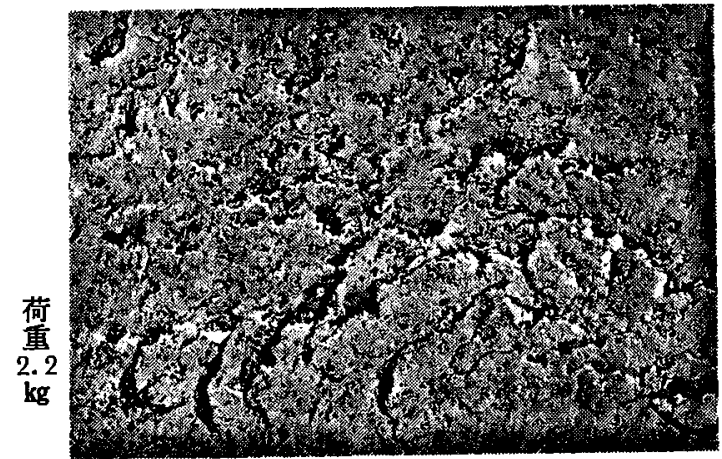

老 化 前



$100^{\circ} \mathrm{C} \times 48 \mathrm{~h}$ 老化後 トラック用タイヤトレッド配合 図12-1 ピコ摩耗試験機による摩耗面のレプリカ写真 $(\times 6,800)$ (試験担当 B社)
がら実験窒結果の予期とは逆転の傾向を示した。このこ とは図11において，摩耗試験条件の低過酷度領域と高過 酷度領域では，犘耗比率の逆転する可能性のあることを 示していることから理解できる.

摩耗試験条件の過酷度からみると，改良ランボーン摩 耗試験機が比較的に実車走行の過酷度に近い領域にあっ たが，一般に実験室摩耗試験機は実車走行よりも高過酷 度領城である，実験室で標準配合と試験配合を過酷度の 異なる試験機あるいは試験条件で摩耗試験を行ない，そ の結果を図11のようにプロットして直線を引けば，実車 走行時の摩耗比率と過酷度をある程度推定することがで きよう。

一方，レプリカ法による電子顕微鏡写真の観察から， タイヤの摩耗現象に近い様子を示すのは，実験室の摩耗 試験機でピコ摩耗試験機ではないかと考えられる。

一般にタイヤの摩耗は複雑な因子が多く、試験条件,摩 耗面の観察，あるいは配合ゴム物性試験などの研究なら びにタイヤの動力学的研究などの今後の進歩 発展によ ク,さらに摩耗機構が解明されていくことを期待したい.

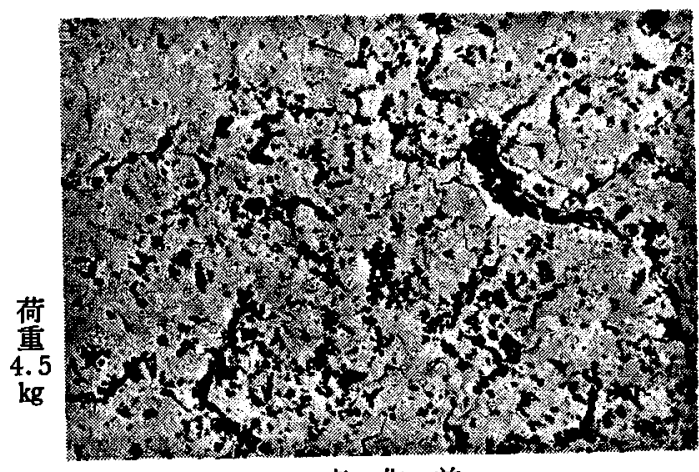

老 化 前

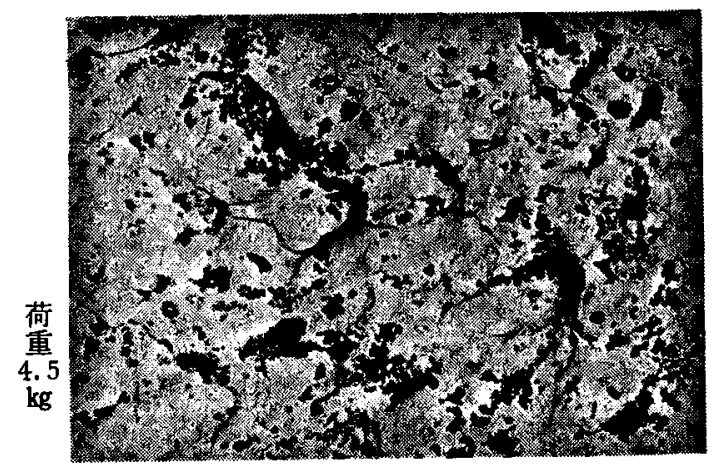

$100^{\circ} \mathrm{C} \times 48 \mathrm{~h}$ 老化後 乗用車用タイヤトレッド配合 
第44巻 第 2 号 (1971)

山本博美
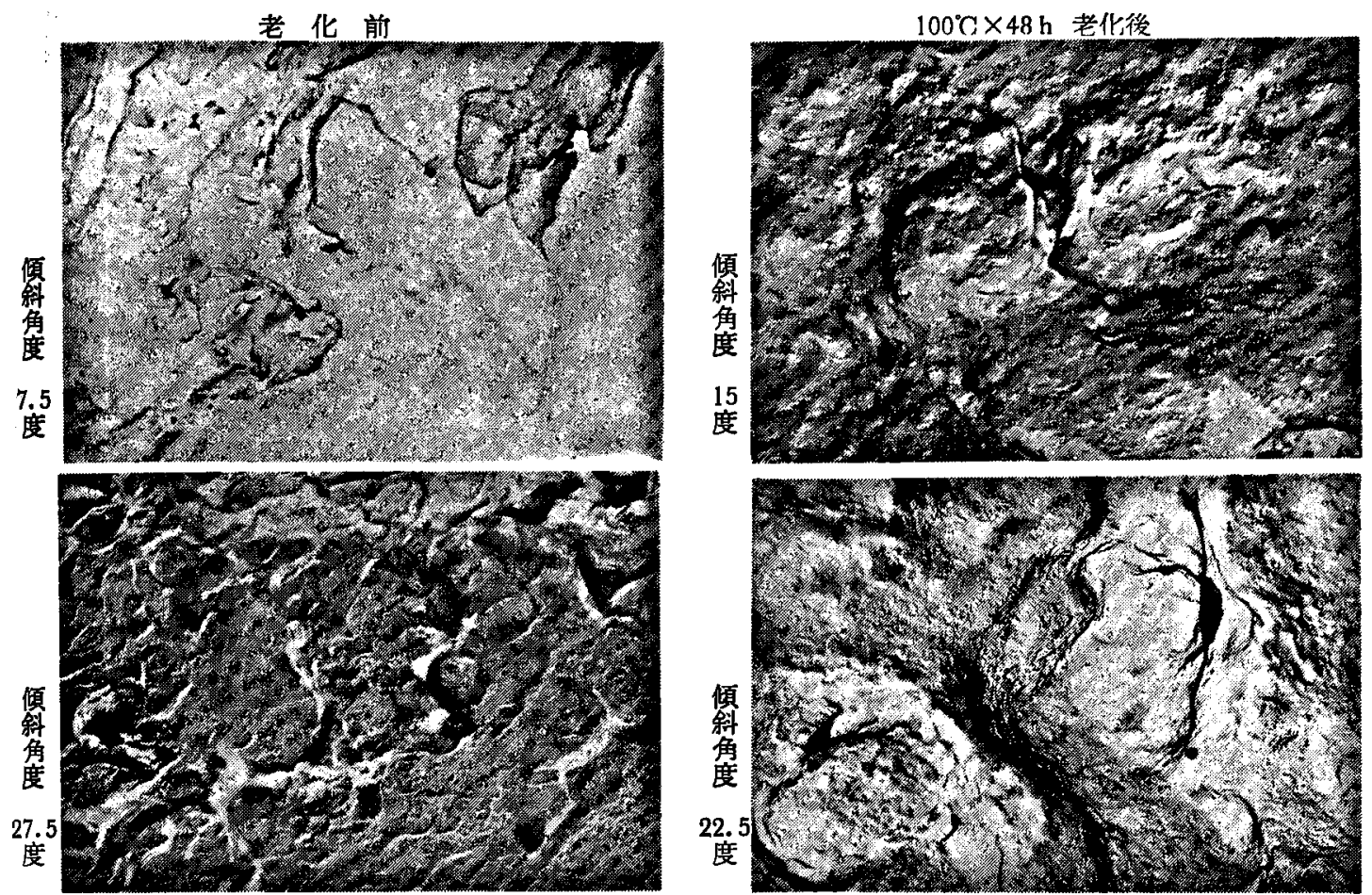

トラック用タイヤトレッド配合
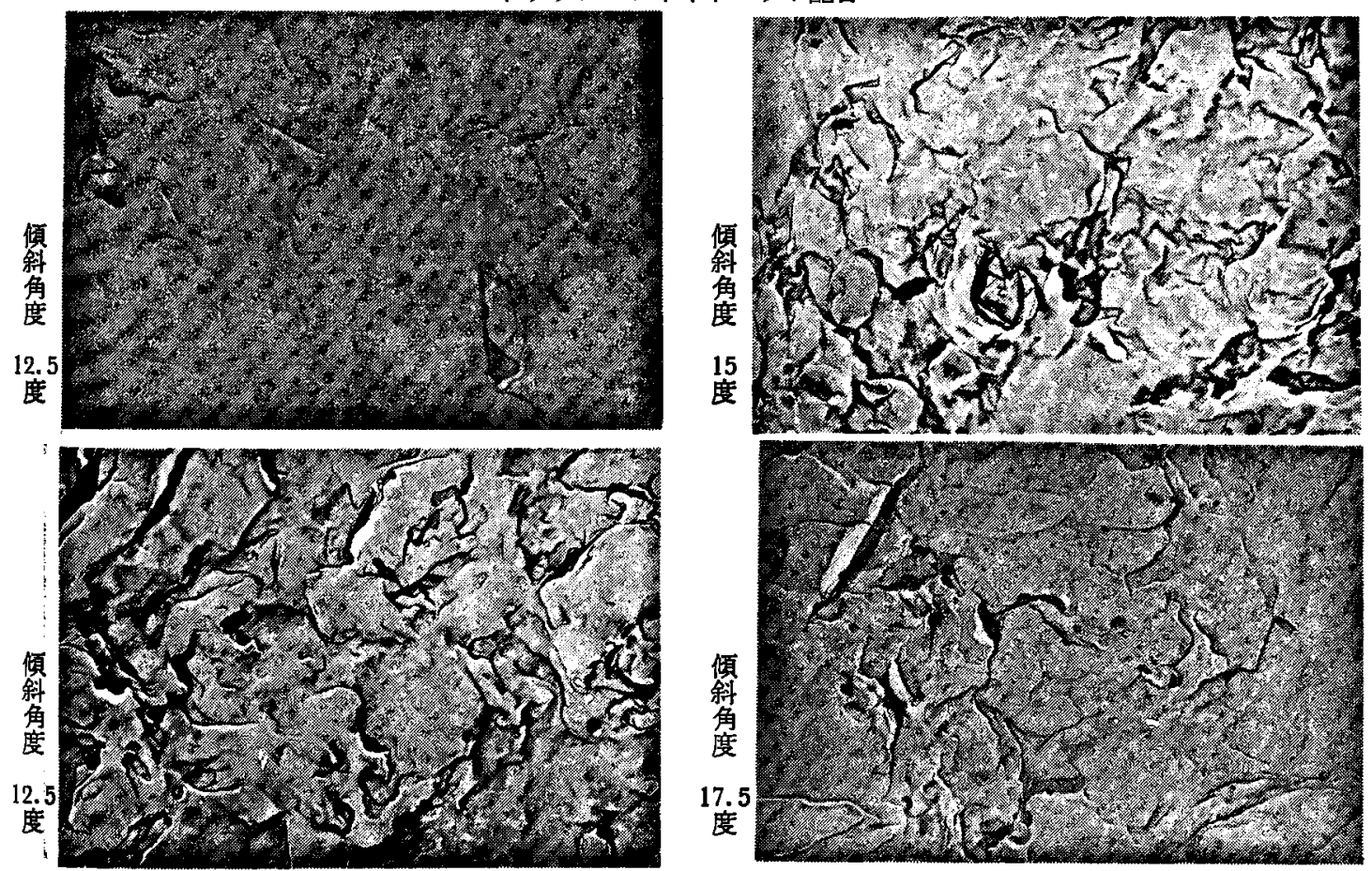

乗用車用タイヤトレッド配合（荷重 $6 \mathrm{lb}$ )

図12-2 アクロン摩耗試験機による摩耗面のレプリカ写真 $(X 6,800)$ （試験担当 B 社）

(107) 
老 化 前
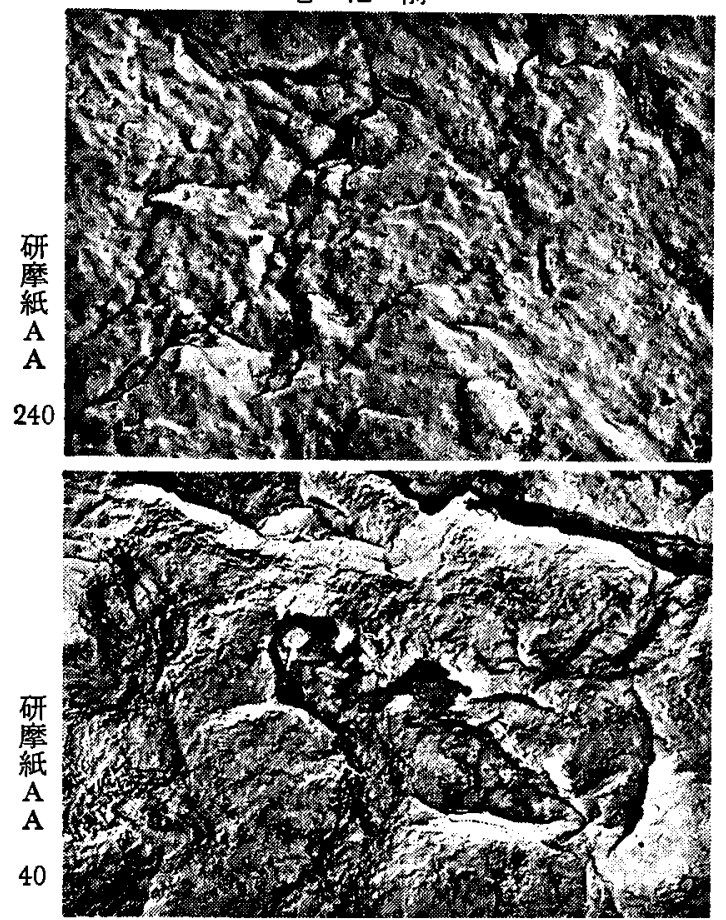

トラック用タイヤトレッド配合

$100^{\circ} \mathrm{C} \times 40 \mathrm{~h}$ 老化後
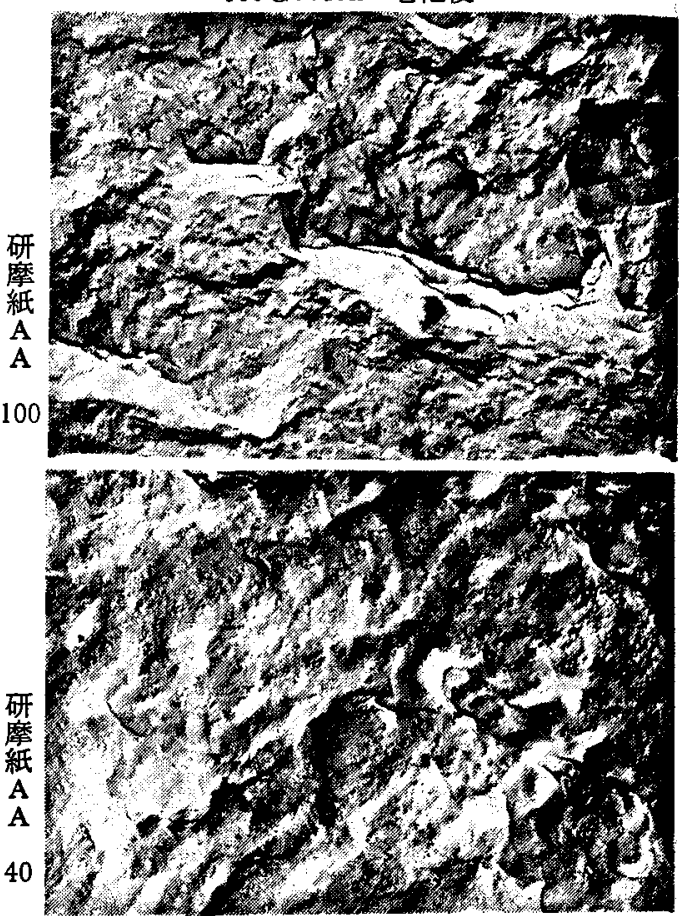
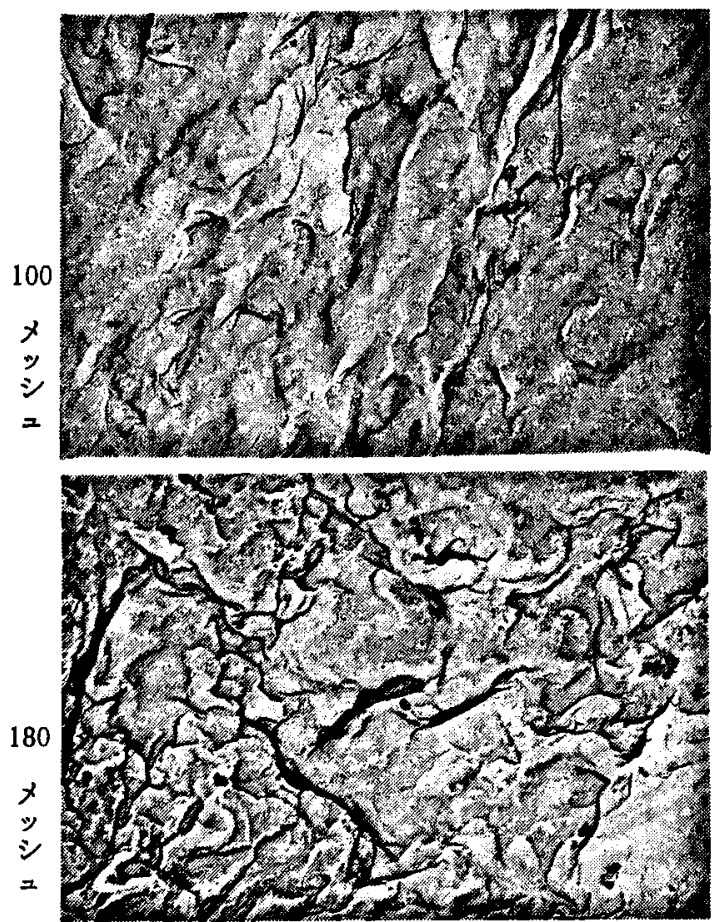
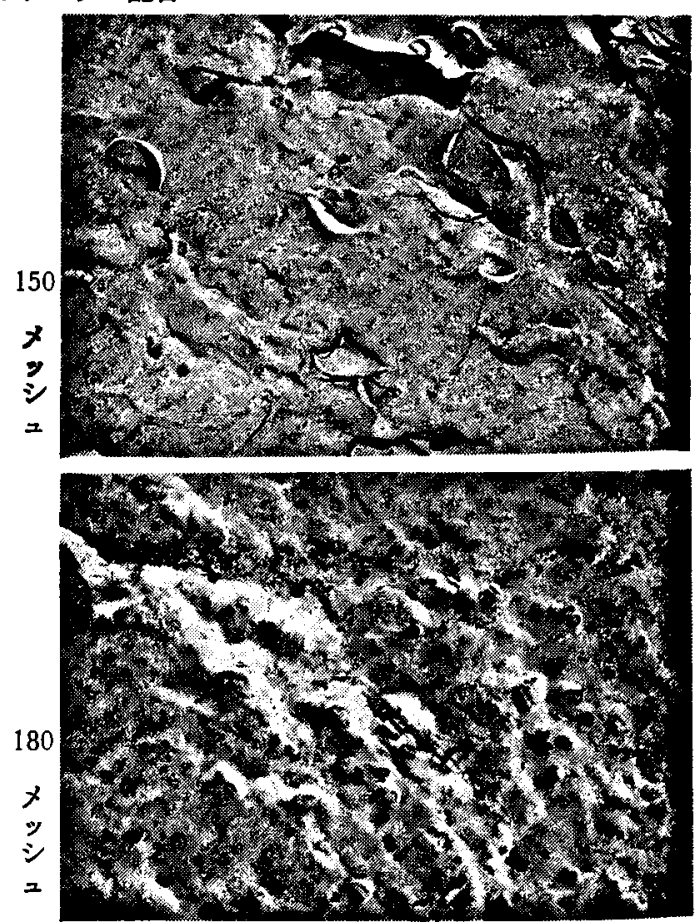

乗用車用タイヤトレッド配合

図12-3 ウイリアムス摩耗試験機による摩耗面のレプリカ写真 $(\times 6,800)$ （試験担当 B 社） 
山本博美

老 化 前
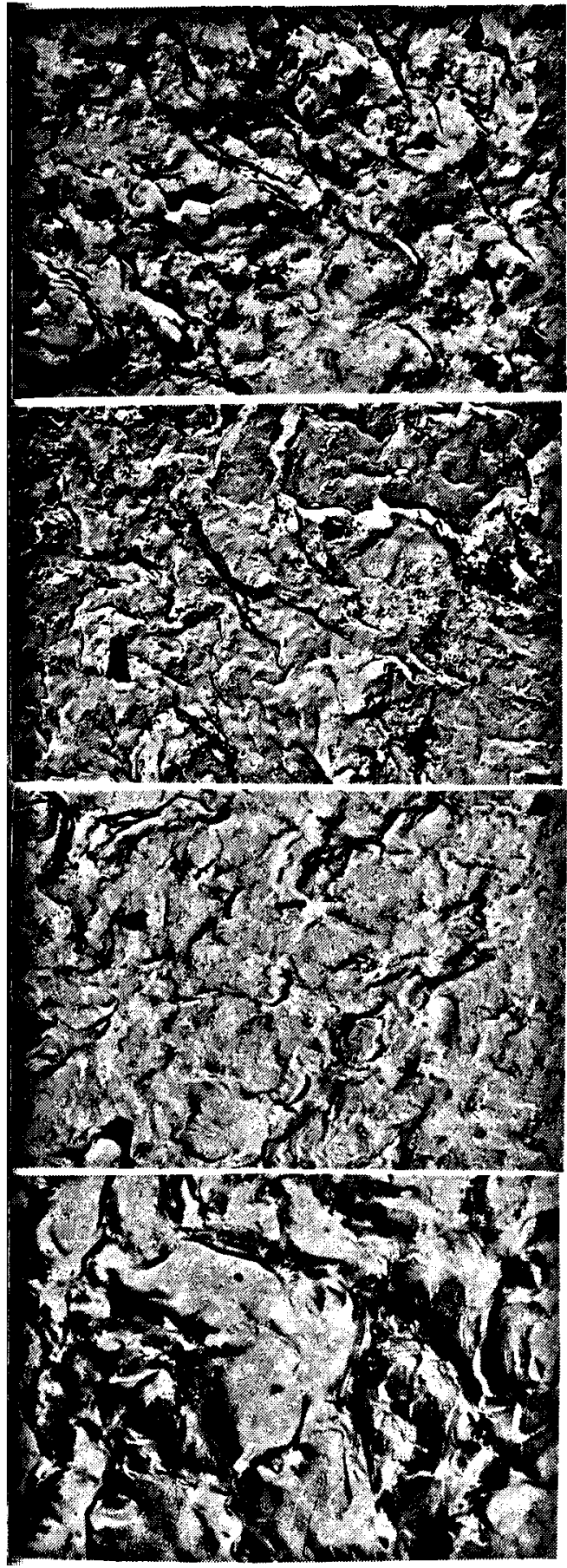

$100^{\circ} \mathrm{C} \times 48 \mathrm{~h}$ 老化後
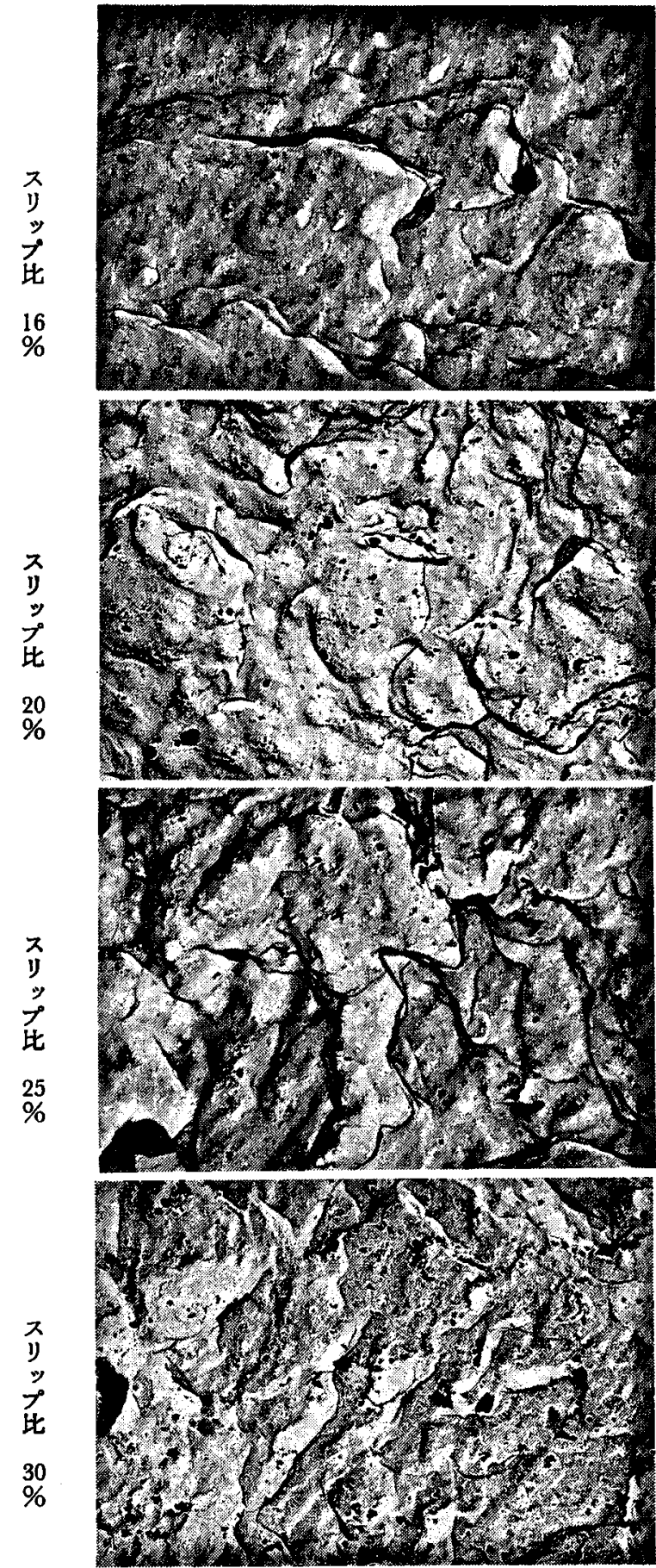

トラック用タイヤトレッド配合

図12-4 改良ランボーン摩耗試駼機による摩耗面のレプリカ写真 $(\times 6,800)$

(試験担当 B 社) 
老 化 前
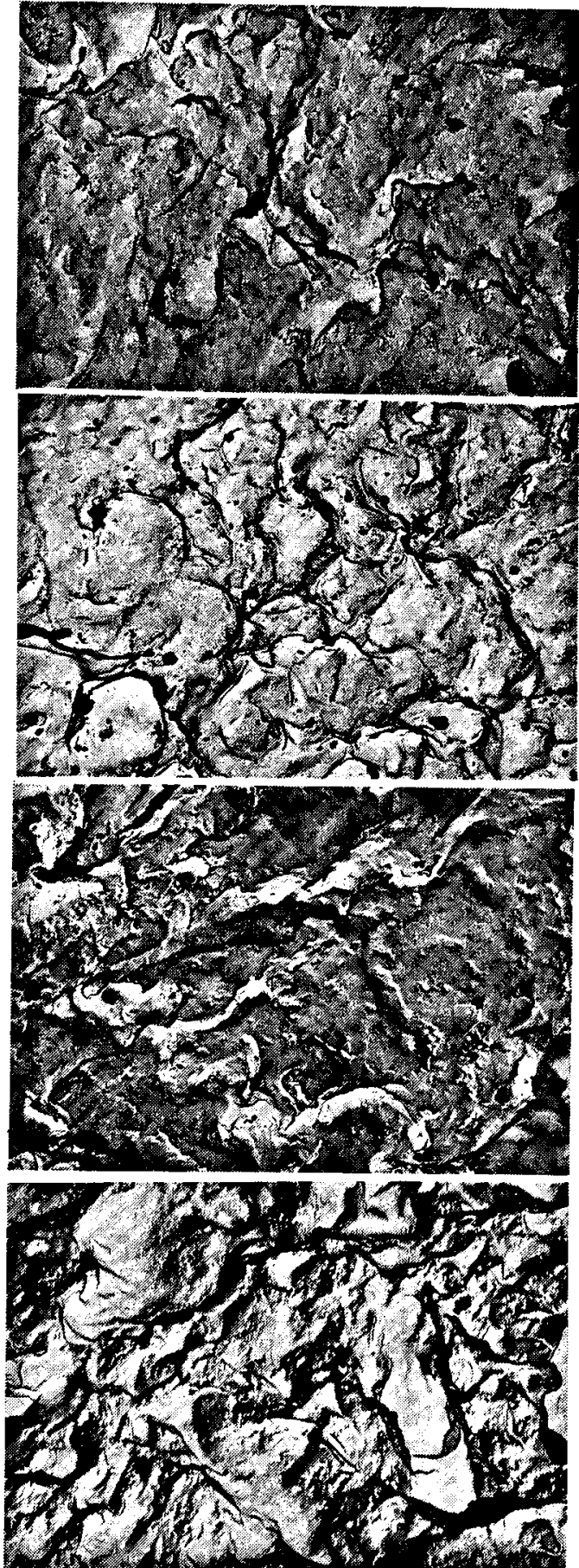

$100^{\circ} \mathrm{C} \times 48 \mathrm{~h}$ 老化後
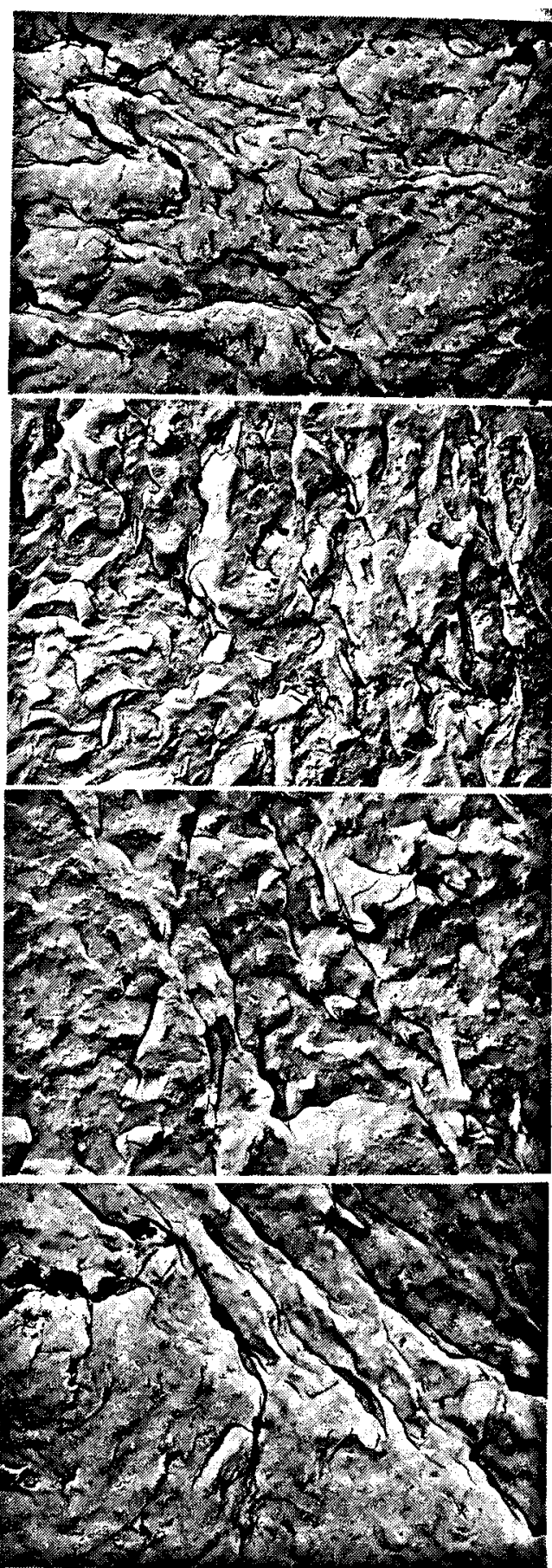

乗用車用タイヤトレッド配合

図11-5 改良ランボーン摩耗試験機による摩耗面のレプリカ写真 $(\times 6,800)$ （試験担当 B 社） 
山本

博

美

第 1 次夏場走行

第 2 次冬場走行

トラック用タイヤ 乗用車用タィヤ

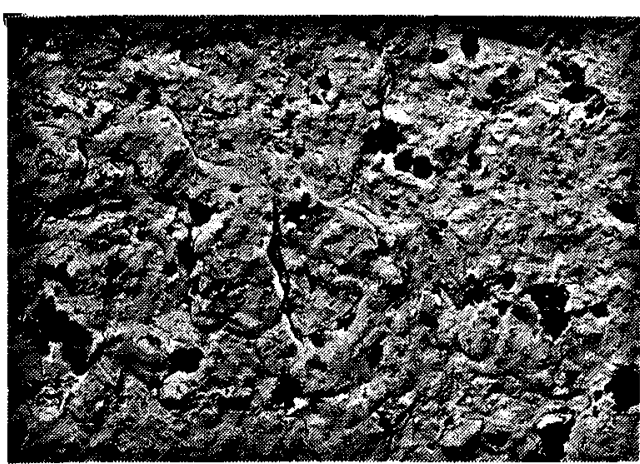

良路走行後

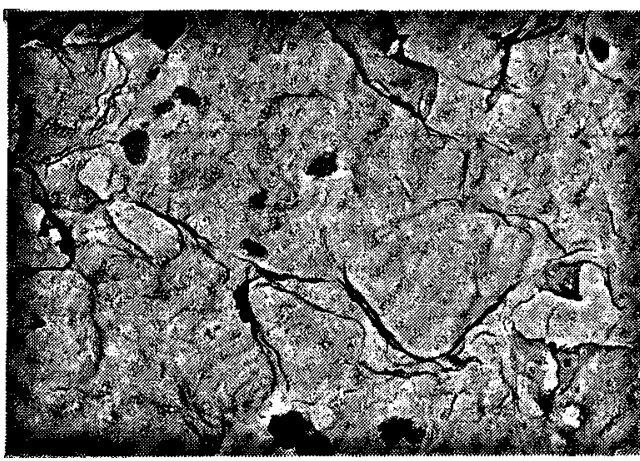

中間路走行後

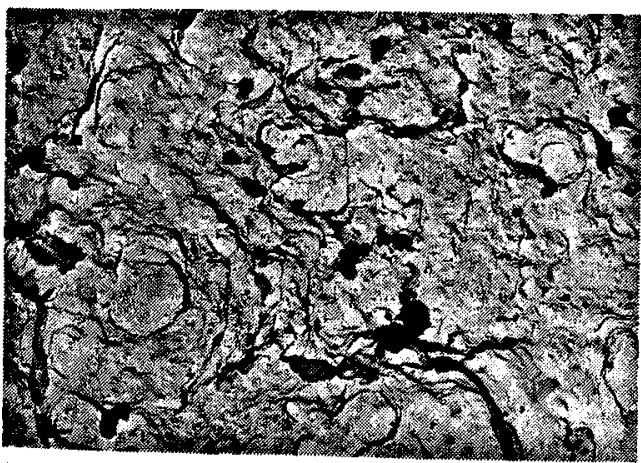

悪路走行後

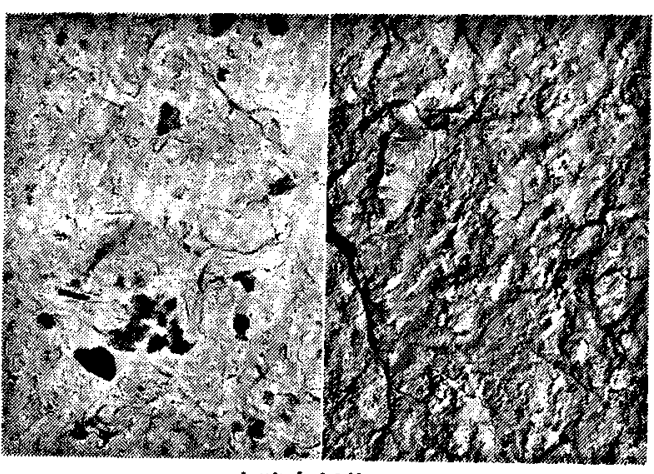

良路走行後

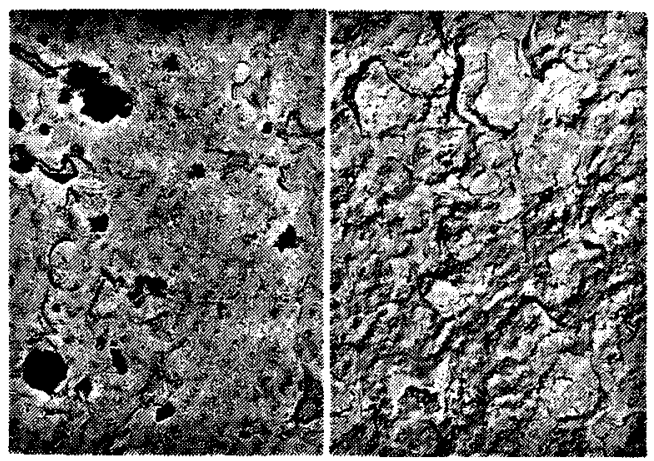

中間路走行後

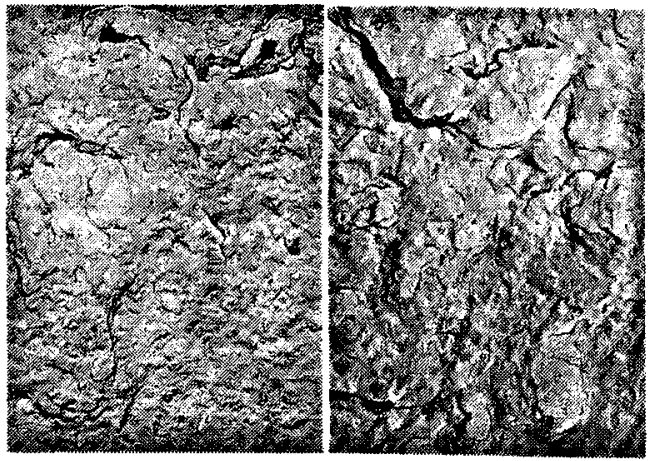

悪路走行後

図12-6 実車走行後のトレッド部摩耗面のレプリカ写真 $(x 6,800)$

（試験担当 B 社） 